O Passeio Público do Rio de Janeiro: Análise Histórica com Auxilio da Representação Gráfica Digital

Naylor Barbosa Vilas Boas

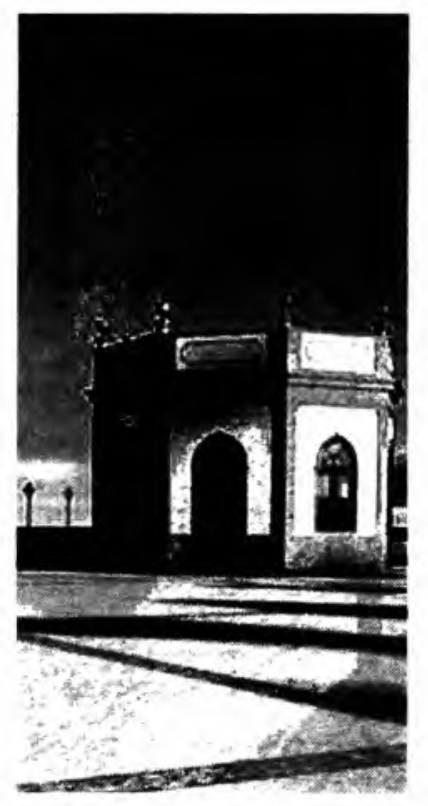

Arquiteto, mestre em história e teoria da arquitetura PROARO / UFRJ, professor substituto da FAU/UFRJ, professor de Arquitetura da Universidade Gama Filho

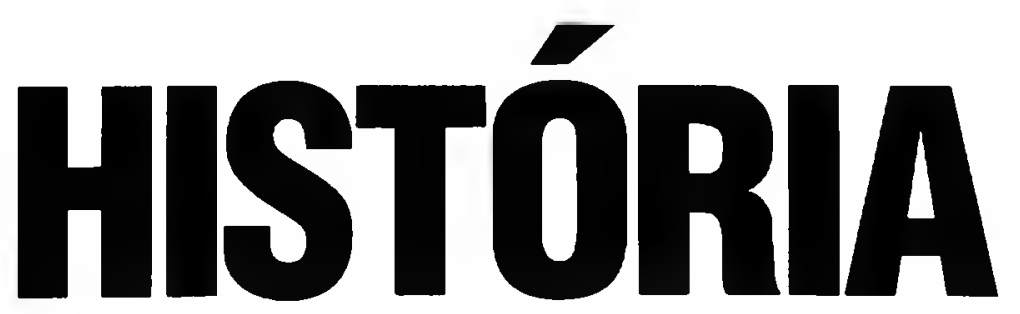


O presente artigo tem por objetivo expor uma breve análise histórica do Passeio Público do Rio de Janeiro, um dos mais importantes jardins públicos da cidade ao longo do século 19, concebido originalmente no século 18 , por mestre Valentim da Fonseca e Silva, ilustre artista do Rio colonial.

Por meio de modernos recursos de reconstrução virtual e modelagem eletrônica, baseados em intensas pesquisas iconográficas e na análise de antigos relatos de viajantes, foram recriados os dois principais momentos desse jardim ao longo desses dois séculos de existência: o Passeio Público original de mestre Valentim e o passeio remodelado na reforma romántica de 1860, por Auguste Glaziou.

Originalmente fazendo parte de um trabalho que trata de questões de análise da percepção do espaço, a utilização de recursos de reconstrução virtual e modelagem eletrônica apresenta-se como uma importante ferramenta de auxilio na reconstituição de espaços que não mais existem fisicamente, permitindo assim a simulação das percepções vivenciadas por um observador hipotético caminhando por eles.

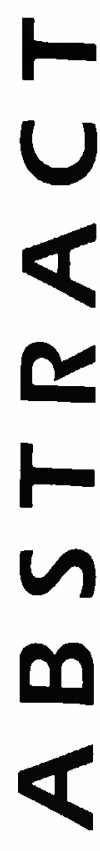

The present article has the purpose to show a brief historical analysis of Passeio Público of Rio de Janeiro, one of the most important city's public garden of 19 th century, originally conceived by mestre Valentim da Fonseca e Silva, a famous colonial Rio artist, by the end of 18th century.

With modern virtual reconstruction and eletronic modeling resources, based on intense iconographical researches and analysis of old travelers reports, it was recreated the two main moments of the garden through those two centuries of existence: the original Passeio Publico of mestre Valentim and the one transformed by the romantic reformation of 1860 's conceived by Auguste Glaziou.

Originally a part of a work that studies questions of space perception analysis, the use of virtual reconstruction resources shows that it is an important tool to recreate spaces that doesn't exists fisically anymore, allowing the simulation of the perceptions experienced by an hipotetical observer walking through there.
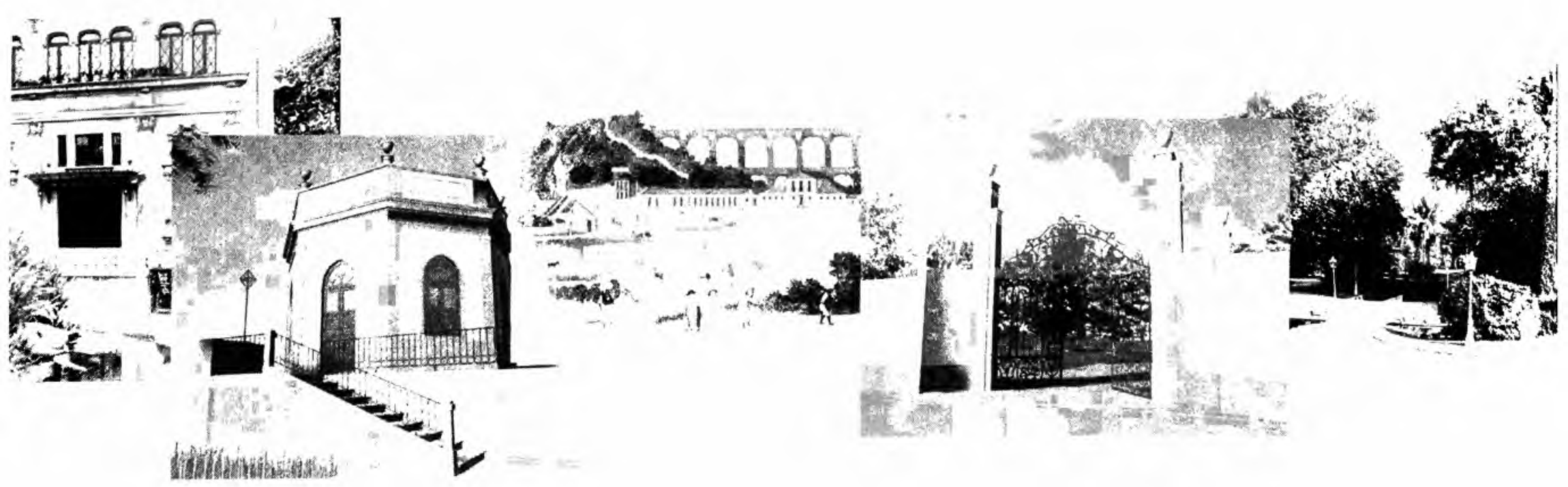


\section{O Passeio Público do Rio de Janeiro: Análise Histórica com Auxílio da Representação Gráfica Digital}

O presente artigo versa sobre o mais importante jardim público existente na cidade ao longo do século 19 - o Passeio Público do Rio de Janeiro. Atualmente contando com pouco mais de dois séculos de existência, esse jardim apresentava-se como um nobre espaço de lazer e marcava com sua localização, no início do século passado, um dos limites do pequeno núcleo urbano da cidade do Rio de Janeiro.

Inicialmente concebido por um dos mais conhecidos artistas do Rio colonial, o mestre Valentim (c. 1745-1813), o Passeio Público sofreu, ao longo de sua história, inúmeras intervençōes que transformariam seus espaços das mais diversas maneiras, algumas de formas extremamente interessantes, outras nem tanto.

Sua principal transformaçāo ocorre na década de 1860, quando o conhecido paisagista francês Auguste Glaziou (1833-1906), também autor de inúmeros trabalhos na cidade, intervém no jardim e transforma-o em um jardim romântico, conhecidos na época como jardins "paisagistas" A intervenção de Glaziou revigora o Passeio Público, naquele momento em lastimável estado de conservação, fazendo com que novamente adquira a devida importância como jardim público e referência como espaço de lazer para a cidade, que nessa época há muito já havia ultrapassado seus antigos limites.

Muito bem recebida pela população na época, como nos conta um dos grandes cronistas do Rio de Janeiro do século 19, Joaquim Manuel de Macedo, a intervenção de Glaziou caracterizava uma tentativa de adequar o Passeio Público ao que existia de mais moderno na questão da elaboração de jardins. De fato, ao contratar um profissional europeu para realizar tal trabalho, o Império fazia um grande esforço para importar uma linguagem estética de acordo com a "modernidade" da época, mesmo que economicamente estivesse se endividando junto à Inglaterra para o custeio da Guerra do Paraguai, em pleno curso, e que sua capital ainda permanecesse como nos tempos coloniais - suja e doente.

No entanto, na década de 40 do século 20, a reforma romântica de Glaziou foi duramente combatida por Josë Marianno Filho, ilustre estudiớso de arquitetura. Inserido em um contexto histórico nacionalista, critica veementemente o trabalho de Glaziou e lamenta a perda do antigo passeio de mestre Valentim, que segundo ele, era legitimamente uma obra de um artista nacional e deveria ser protegido a qualquer custo. 
Mesmo compreendendo o contexto histórico no qual Marianno Filho estava inserido ao expor seus pensamentos, não se compartilha em absoluto de sua opinião. De fato, apesar de não se concordar com a busca por uma "modernidade" presente constantemente em nosso país, em útima instância responsável pela intervenção romântica no Passeio Público, o que aqui se pretende expor é que Auguste Glaziou foi profundamente coerente em seu trabalho, não modificou a estrutura conceitual do passeio e, além disso, enriqueceu de modo substancial o jardim, de acordo com os preceitos românticos aplicados em sua elaboração.

\section{As Origens}

A história do Passeio Público da cidade do Rio de Janeiro tem origem no ano de 1779 , quando o vice-rei $D$. Luís de Vasconcelos toma a decisão de aterrar a lagoa do Boqueirão da Ajuda, imenso alagadiço que existia no local e que impedia, de certa forma, a expansão natural da cidade para as regiões atuais do Flamengo e Botafogo.

Outra justificativa para o aterramento provém de preocupações sanitárias. A região era utilizada pela população para despejo de lixo e dejetos humanos onde, à noite, escravos apelidados de "tigres" iam ali despejar o esgoto da casa de seus senhores.

Confiado o trabalho ao artista Valentim da Fonseca e Silva (ca.1745-1813), o conhecido mestre Valentim, dá-se início aos trabalhos em 1779, sem o necessário apoio financeiro por parte da

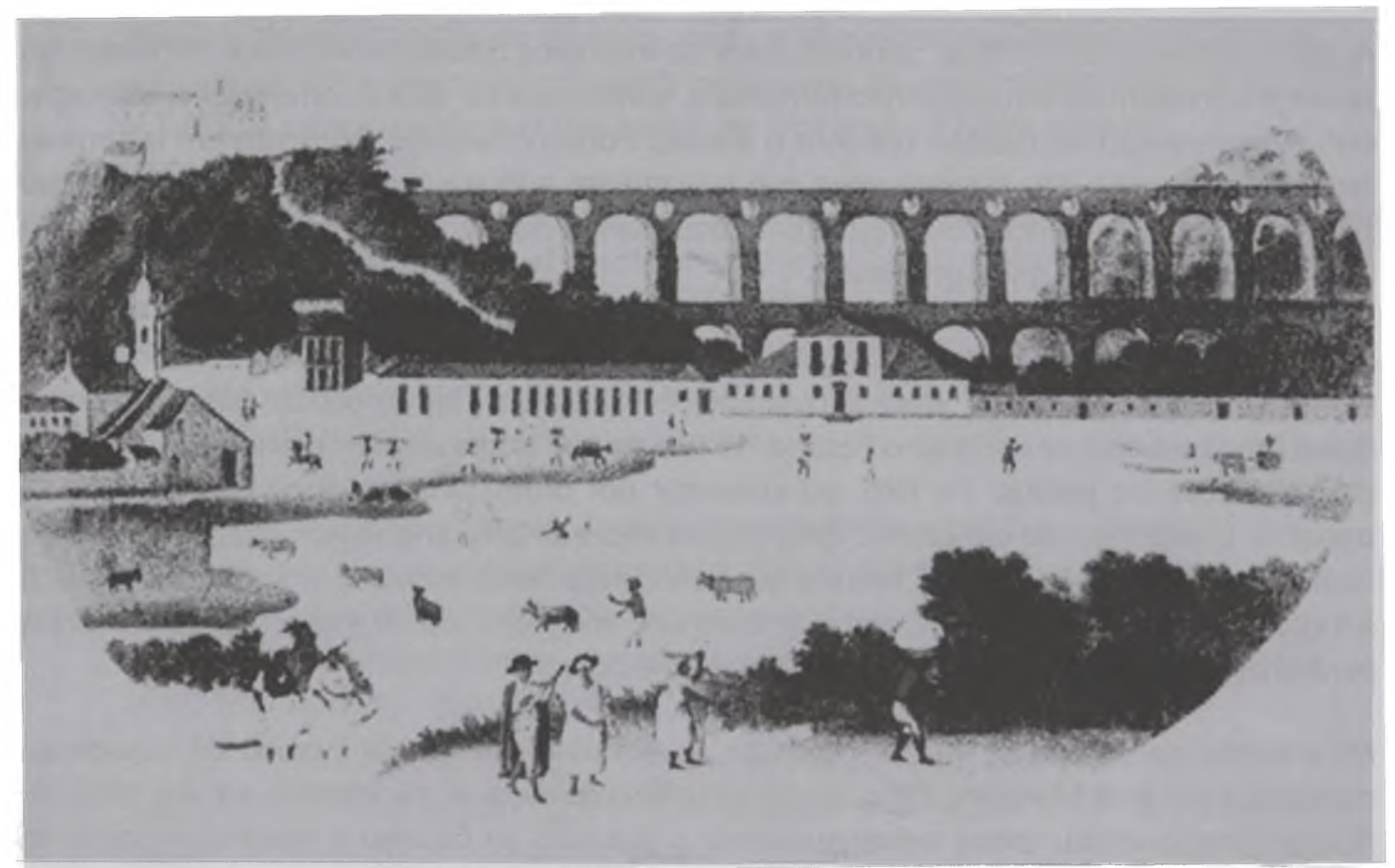

Figura 1: Aspecto da antiga lagoa do Boqueirão da Ajuda. Ao fundo, os atuais Arcos da Lapa

Fonte: MACEDO, Joaquim N. de. Um passeio pela cidade do Rio de Janeiro. Rio de Janeiro: Garnier, 1991. p. 40-41 
metrópole. A mão-de-obra e a verba utilizada foram provenientes do trabalho de "vagabundos e vadios" que perambulavam pela cidade. O vice-rei $D$. Luís de Vasconcelos mandou recolher essas pessoas das ruas e confiná-las no presídio da ilha das Cobras. Aqueles que tinham ofício trabalhariam e a renda gerada seria utilizada para o custeio das obras, e aqueles que nada sabiam fazer seriam utilizados efetivamente nas obras do aterramento.

Escreve o vice-rei em ofício de 1781: "Havendo em toda parte muita casta de vadios, que cometem insultos e extravagâncias inauditas, não é de admirar que no Rio de Janeiro, aonde o maior número dos seus habitantes se compõe de mulatos e negros, se pratique todos os dias grandes desordens, que necessitam ser punidos com demonstraçôes severas, que sirvam de exemplo e de estímulo para se coibirem, ainda que de nenhum modo se deve esperar que o sejam na sua totalidade."

O material para o aterramento veio do desmonte do morro das Mangueiras, situado onde hoje se localiza a rua das Marrecas. Foi tarefa complexa, já que a lagoa do Boqueirão da Ajuda ocupava uma área muito extensa, de acordo com a cartografia da época.

A inauguração se deu em 1783, sendo que se desconhece o dia e o mês de tal evento. Aparentemente, inexistem informações registradas sobre sua abertura ao público, sendo que o primeiro grande evento realizado no local foram os festejos feitos pela população para homenagear o casamento do príncipe D. João com a princesa D. Carlota Joaquina, ocorrido em Portugal, em 1786.

Com a inauguração do Passeio Público, o Rio de Janeiro colonial ganhou uma nova área para o lazer da população, de caráter inédito para a cidade. Antes, a então praça do Carmo, hoje praça XV de Novembro, era precariamente utilizada como lugar de lazer e de passeio. Porém, era um local de repartições públicas, carente de vegetação e bastante movimentada, com um fluxo constante de marinheiros e escravos. O Passeio Público supria justamente essa carência de um lugar calmo e recolhido da agitação que ali reinava.

Enquanto a administração de D. Luís de Vasconcelos perdurou, o Passeio Público teve sua manutenção assegurada e era bastante freqüentado pela população. Segundo Joaquim Manoel de Macedo, "nas noites de brilhante luar dirigiam-se alegremente para o Passeio Público numerosas familias, galantes ranchos de moças, e por consequência cobiçosos ranchos de mancebos, e todos iam, divididos em círculos de amigos, sentar-se às mesas de pedras, $e$ debaixo dos tetos de jasmins odoriferos ouviam modinhas apaixonadas e lundus travessos cantados ao som da viola e da guitarra, rematando sempre esses divertimentos com excelentes ceias dadas ali mesmo" ${ }^{2}$

(1) VASCONCELOS E SOUSA, Luiz de. Novas culturas, obras publicadas, rendas e despezas do Brasil nos tempos coloniaes: officio do vice-rei Luiz de Vasconcellos datado de 15 de julho de 1781, para o sr. Martinho de Mello e Castro. Revista do Instituto Historico e Geographico Brazileiro, Rio de Janeiro, tomo 51, parte segunda, p.183-208, 1888, citado por SEGAWA. Hugo. AO amor do público - Jardins no Brasil. São Paulo: Studio Nobel: Fapesp, 1996. p. 83.

(2) MACEDO, Joaquim M. de. Um passeio pela cidade do Rio de Janeiro. Rio de Janeiro: Garnier, 1991. p. 67. 


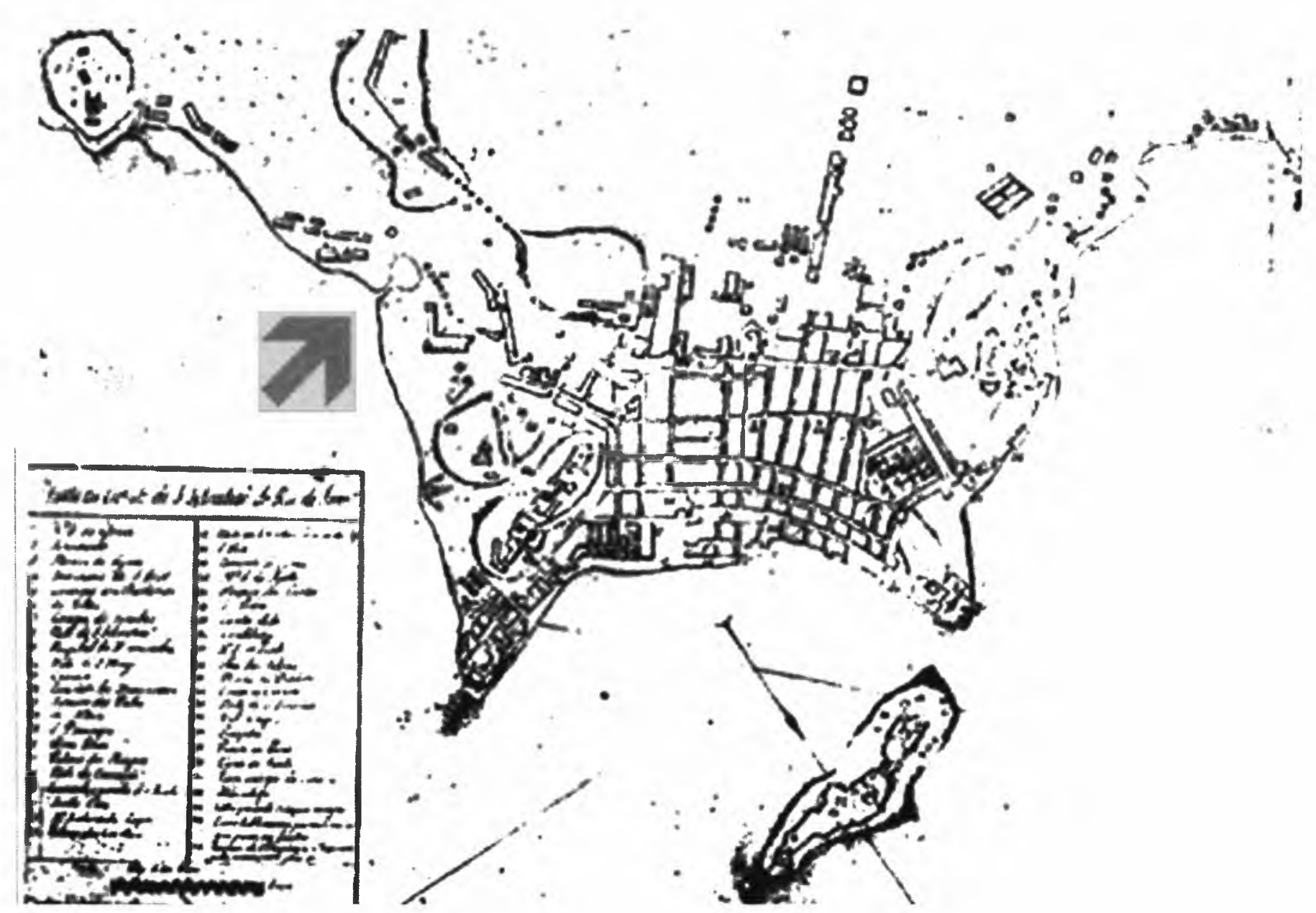

Figura 2: Mapa da cidade em 1775. Em destaque, a lagoa do Boqueirão da Ajuda Fonte: MACEDO, Joaquim N. de. Um passeio pela cidade do Rio de Janeiro. Rio de Janeiro: Garnier, 1991. p. 40-41.

Em 1789, estourando a Inconfidência Mineira, as atitudes do vice-rei em relação à cidade e à população se transformam. Agora desconfiado e temeroso, D. Luís de Vasconcelos "multiplicou os segredos, não abriu um só instante o coração à piedade, tunvou seu espírito com a suspeita, (...). encheu a cidade do Rio de Janeiro de receios aterradores" ${ }^{\prime 3}$

É possível que o declínio e o abandono do passeio como espaço de lazer para a população, muito observado pelos viajantes e cronistas do século seguinte, tenha começado nessa ocasião. Ainda segundo Macedo, "o povo não se lembrou mais de folgar e rir, e as flores do Passeio Público logo começaram a murchar " ${ }^{4}$. Substituído em 1790, D. Luís de Vasconcelos não mais pôde dar a devida assistência ao Passeio Público de sua criação.

Seu sucessor imediato, D. José Luiz de Castro, conde de Rezende, conhecido como homem desconfiado e melancólico, é lembrado por Macedo como "uma verdadeira praga que caiu sobre a cidade" 5 , desfazendo alguns dos benefícios que seus antecessores haviam implantado no Rio de Janeiro.

(3) Idem. p. 67.

(4) Ibid., p. 67.

(5) Ibid., p. 68. 
Em 1806, o último dos vice-reis, conde dos Arcos, resolveu fazer alguma manutenção no local. O coqueiro de ferro sobre a Fonte dos Jacarés, já derrubado há tempos, foi substituído por um busto de Diana em mármore, de autoria do mestre Valentim. Construiu-se ainda duas grandes pirâmides de granito em frente da fonte, sendo esta sua última obra pública.

Em 1808, a recém-chegada família real manda retirar os lampiōes do terraço e instalá-los no largo do Paço e na quinta da Boa Vista.

Em 1817, o Passeio Público sofreu nova intervenção, já que se encontrava em estado bastante precário. O terraço, parcialmente destruído pelo mar, foi reconstruído e alargado. Os seus dois pavilhōes originais, destruídos, foram demolidos e somente foram substituídos por dois novos em obras de manutenção realizadas em 1841. Os dois novos pavilhões, de planta octogonal, mantiveram a mesma intenção decorativa em seu interior, com a pintura de murais representando cenas cotidianas do Rio de Janeiro colonial.

Porém, ao que parece, as obras de 1817 não devolveram o passeio ao uso da população, como nos idos tempos de D. Luís. Segundo o capitão prussiano Ludwig von Rango, que ali passou em 1819. ".../ realmente uma lástima, um lugar tão bonito e bem arborizado, que se poderia tornar realmente belo com pequeno custo. Mas assim é tudo aqui. Nada se faz com cuidado, tudo se deixa largado à lei da natureza"

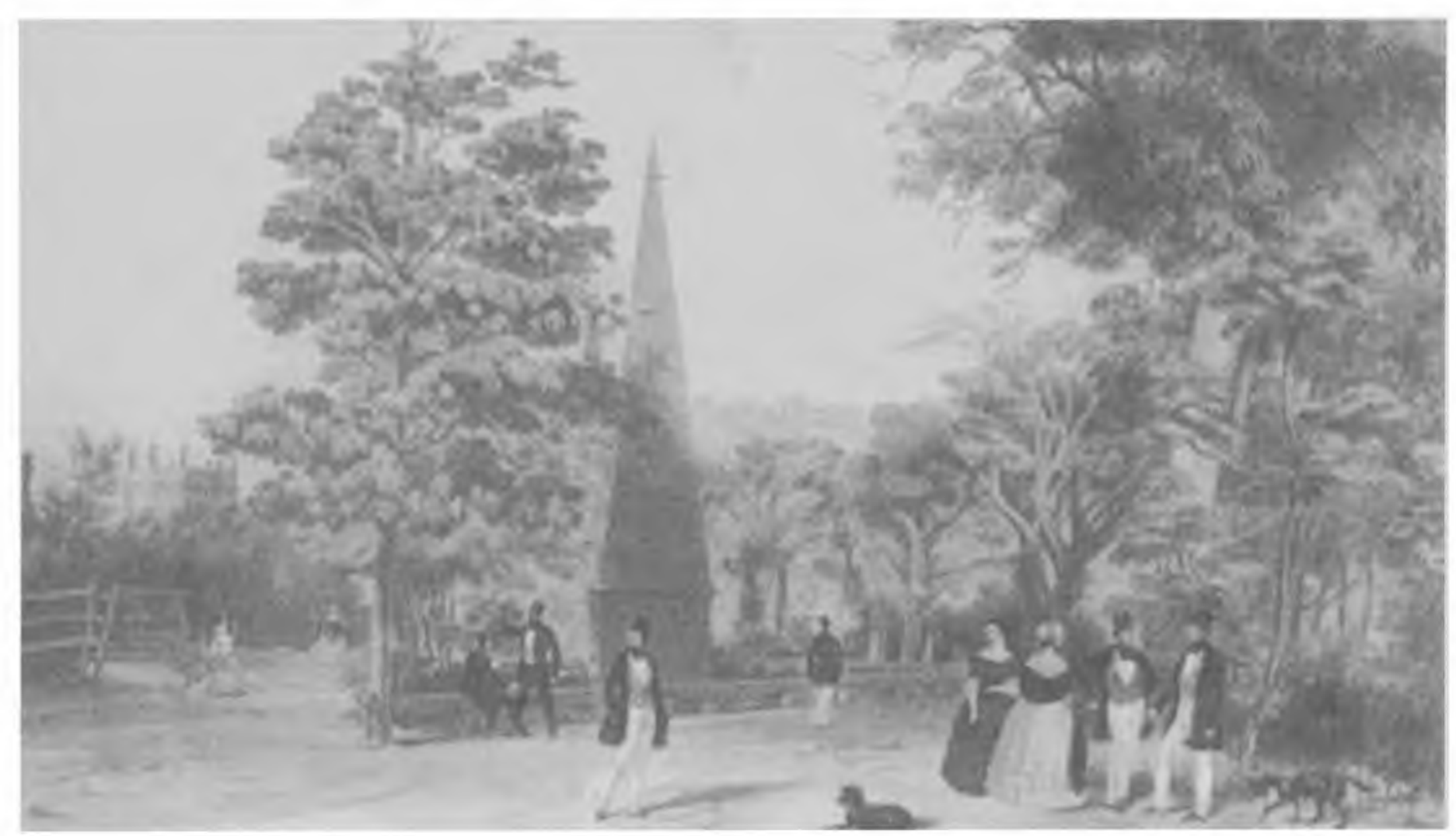

Figura 3: O Passeio Público em litografia de Alfredo Martinet, 1847. Nota-se, no centro, a pirâmide de granito. No fundo, à esquerda, o topo de um dos pavilhōes no terraço

Fonte: SEGAWA, Hugo. Ao amor do público - jardins no Brasil. São Paulo: Studio Nobel/Fapesp, 1996. p. 101

(6) LEITHOLD, T. von, RANGO, L. von. O Rio de Janeiro visto por dois prussianos em 1819. São Paulo: Nacional, 1966. 
Em 1824, com a nomeação do botânico frei Leandro do Sacramento (1779-1829), inspetor do Jardim Botânico ${ }^{7}$ e do Passeio Público, o espaço recebeu novamente a merecida atenção por alguns anos. Frei Leandro ministrava aulas de botânica em um pavilhão dentro do jardim, trabalhando com afinco para o embelezamento do passeio público. Segundo o viajante Ernst Ebel, "o parque andou muito tempo abandonado e só recentemente, graças aos esforços do grande botânico, frei Leandro (...), está sendo recuperado e diariamente embelezado" ${ }^{8}$.

Com a morte de frei Leandro, em 1829, caiu novamente o local no esquecimento das autoridades.

Obras significativas, somente a substituição dos muros laterais por gradil de ferro em 1835, a construção, como já dito, de dois novos pavilhões octogonais no lugar dos antigos, construídos por mestre Valentim, em 1841, e em 1854, a construção de mais dois pavilhões nos jardins e a instalação de iluminação a gás no local.

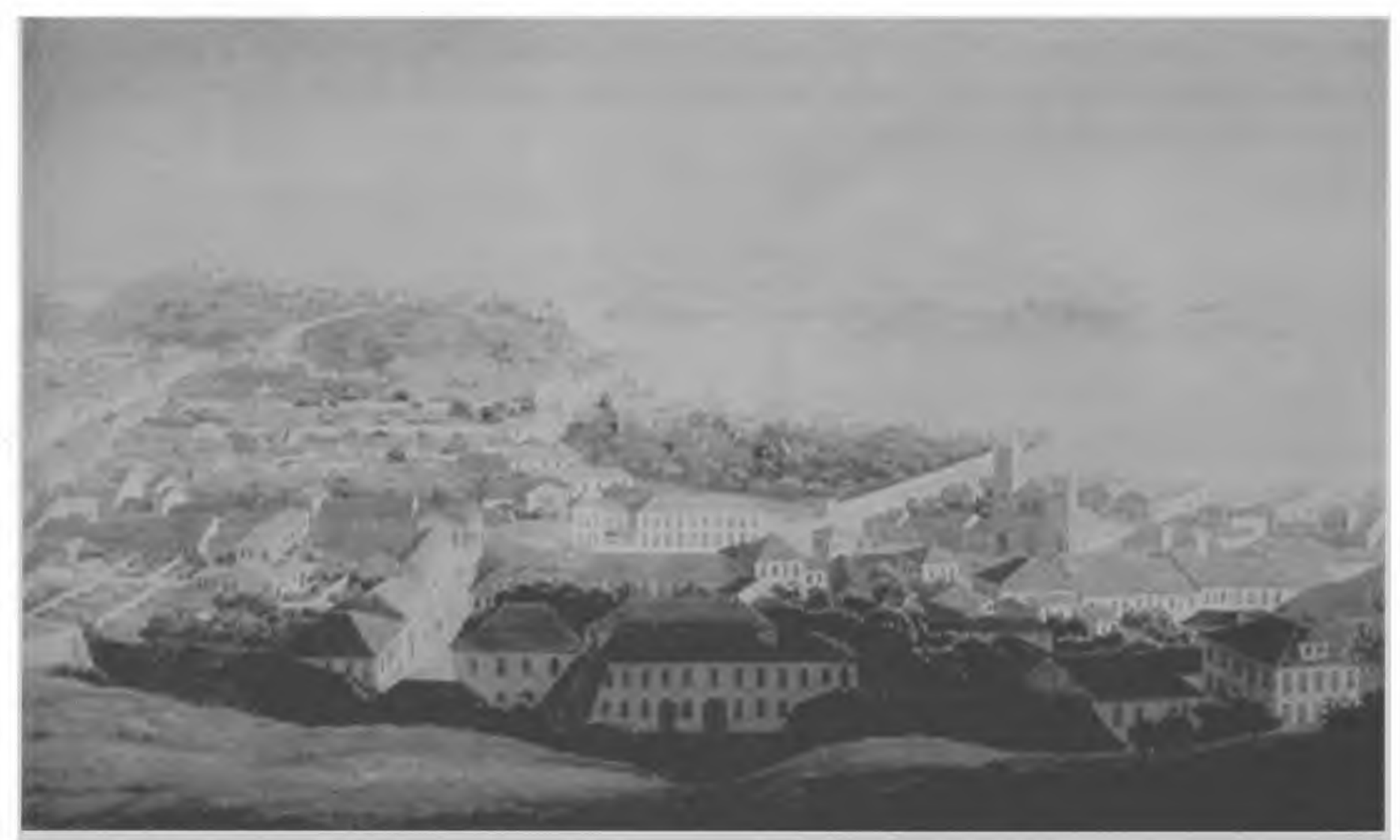

Figura 4: Vista do outeiro da Glória, meados do século 19. Ao fundo, é possível observar a massa vegetal do passeio debruçada sobre o mar

Fonte: http://www.ourworld.compuserve.com/homepages/albertop/rio.htm

(7) Nessa época, o Passeio Público já não era o único parque público da cidade. Com a criação do Jardim Botânico por D. João VI, em 1808, o carioca podia dispor dessa outra opção para o lazer, porém ainda um tanto afastado para uma freqüência mais significativa.

(8) EBEL, Ernst. O Rio de Janeiro e seus arredores em 1824. São Paulo: Nacional, 1972. 
Mesmo com essas pequenas intervenções, a freqüência no Passeio Público não se torna significativa, como nos mostra a correspondência de viajantes que por ali passaram. Segundo sua narrativa, o viajante Hermann Burmeister, que esteve na cidade entre 1850 e 1852, estranha o fato de a população não utilizar o "único lugar para divertimentos coletivos". Cita também o fato de a sociedade carioca não ganhar as ruas ao entardecer, preferindo o recolhimento ou o refúgio nas chácaras.

É interessante notar a projeção que esse europeu faz dos costumes de sua sociedade, esperando encontrar aqui os mesmos costumes da burguesia européia, que já consolidava a idéia da utilização dos espaços públicos de lazer para "ver e ser visto". Conta-nos Burmeister: "Eu esperava, porém, que, ao escurecer, com a temperatura mais amena, pudesse encontrar, nos lugares de recreio e nas praças públicas, uma sociedade bem vestida a fazer seu passeio, mas isso não acontece." "Ao contrário, encontra por aqui uma sociedade bastante fechada, voltada para hábitos caseiros e familiares, pouco inclinada para relações sociais às quais estava acostumado. Segundo ele. "...) uma pessoa que não tem relações ou amigos, no Rio, não poderá fazer mais que levar uma vida retraída e contemplativa ou então dedicar-se ao estudo da natureza" ${ }^{\prime 0}$

\section{A Concepção do Mestre Valentim}

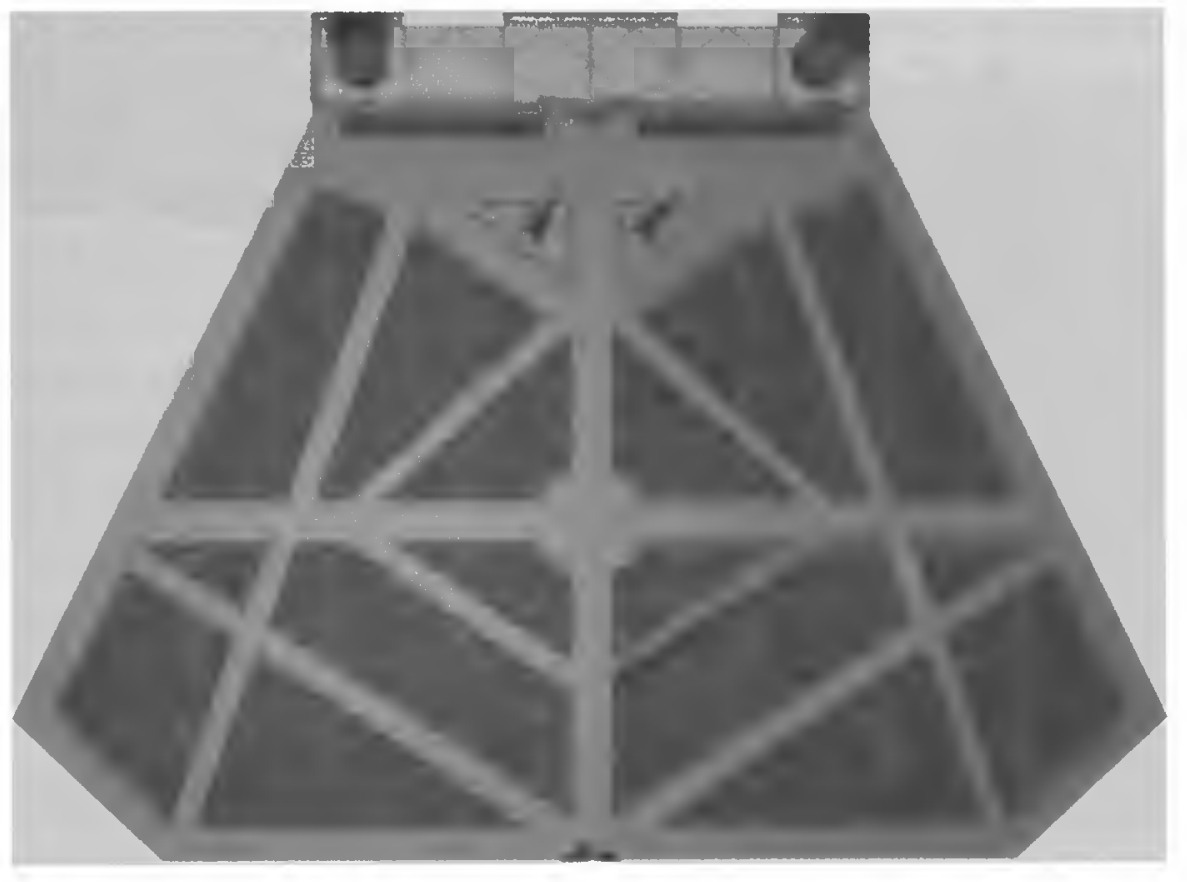

Figura 5: O Passeio de Valentim reconstituído por computaçāo gráfica: visão geral Fonte: Autor

(9) BURMEISTER, Hermann. Viagem ao Brasil através das provincias do Rio de Janeiro e Minas Gerais. Săo Paulo: Livraria Martins, 1952. p. 178.

(10) Idem. p. 178. 
O traçado de mestre Valentim para o Passeio Público seguia a concepção comumente encontrada nos chamados jardins cortesãos europeus, presentes nas residências palacianas do século 16 até o século 18, identificados principalmente com o estado absolutista. Segundo Anna Maria de Carvalho, tais jardins "compunham-se de canteiros e aléias ordenadas num traçado geométrico, onde predominava a linha reta, e submetidos à um eixo central, cujo foco era (...) o palácio e o ponto de fuga (...) um esplêndido panorama (...). Complementavam sua decoração obras escultóricas e arquitetônicas (...) representando símbolos de antigos conhecimentos da História (pirâmides, escadarias, pavilhões etc.) e da Natureza (fontes, cascatas e espelhos d'água, elementos talhados da fauna e da flora locais)" "

De fato, todos os elementos descritos acima são utilizados por mestre Valentim em sua concepção para o Passeio Público. Como visto na Figura 5, seu traçado compõe-se de alamedas retilíneas que percorriam toda a extensão do jardim, marcada fortemente pela existência de dois eixos principais que se cruzam, formando uma praça central.

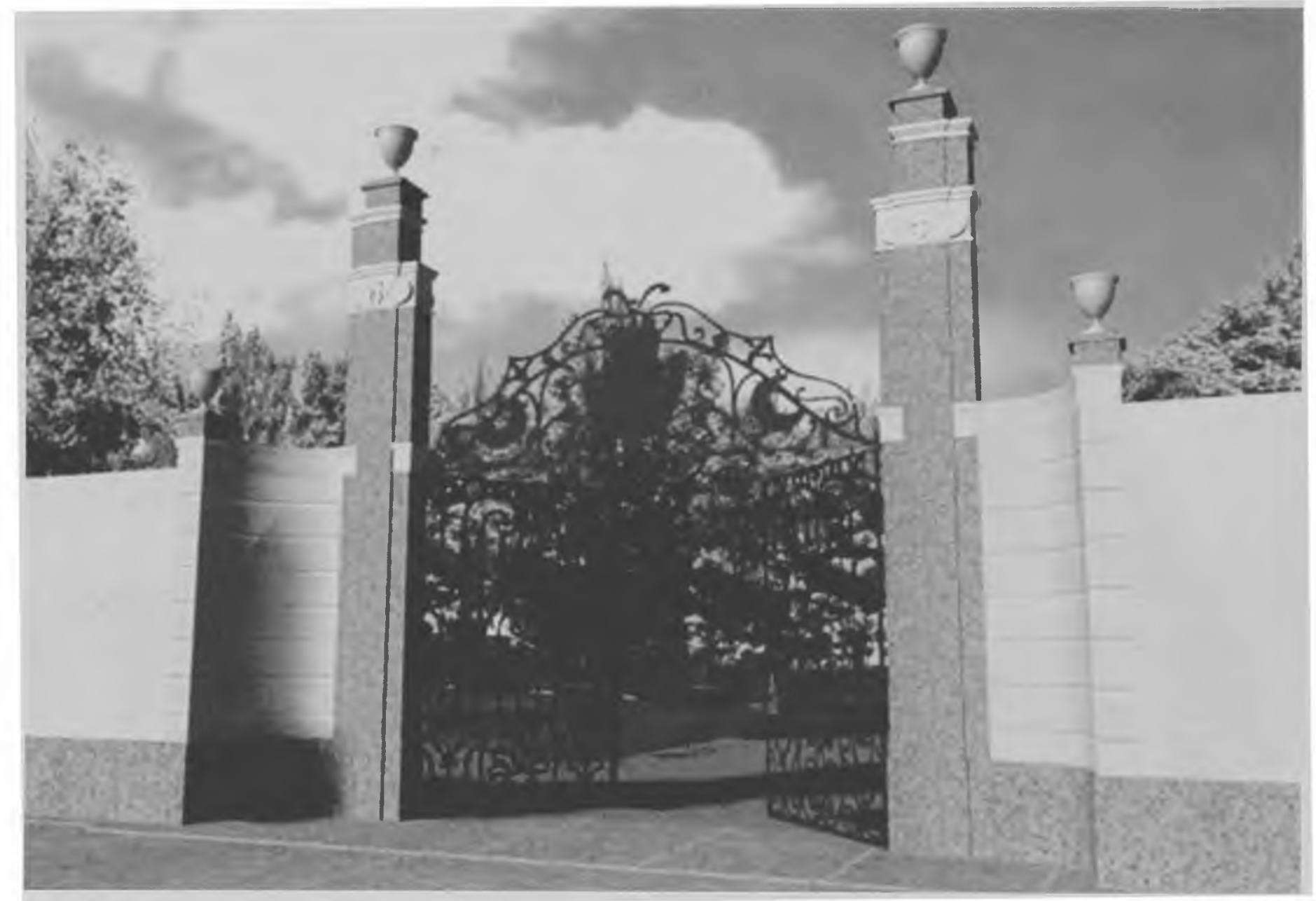

Figura 6: O portão do Passeio Público, ainda hoje existente, aqui reconstituído digitalmente Fonte: Autor

(11) CARVALHO, Anna Maria Monteiro de. O Passeio Público e o Chafariz das Marrecas de Mestre Valentim. Gávea. Rio de Janeiro: PUC-RJ, n. 7, dez./ 1989, p. 87 
A entrada se dava, como ainda hoje, pela rua do Passeio. Segundo Macedo, "no meio da face que concorreu para formar a rua do Passeio, rasgava-se o muro, dando lugar ao portão de entrada, que era todo de ferro e firmado em dois pilares de pedra lavrada" ${ }^{12}$

O jardim era cercado por muros de alvenaria com repetidas aberturas gradeadas, ornamentadas com vasos de cantaria, de frente para a rua do Passeio e nas laterais esquerdas voltadas para o largo da Ajuda, e, na direita, para o largo da Lapa do Desterro.

A alameda principal terminava em um outeiro artificial, adornado por um coqueiro de ferro pintado na parte superior, e de onde uma cascata despejava água sobre dois jacarés de bronze, até hoje existentes no local.

"O outeiro fora todo formado de pedras sobrepostas como ao acaso, mas com admirável efeito. (...) Quase na base do outeiro dois jacarés também de bronze, parecendo recrear-se entrelaçados fora do seu ninho, mostravam-se soberbos, lançando pela boca aberta cópia de água claríssima, que ia, com a que deitavam as aves, ajuntar-se em um tanque semicircular, que rodeava a cascata, e onde se reproduziam as imagens dos jacarés. Sobre o cume do outeiro, enfim, eleva-se um magnífico coqueiro de ferro, pintado ao natural e tendo mais de 20 palmos de altura. ${ }^{13}$

Na parte de trás do outeiro existia uma estátua de mármore de um menino, segurando um cágado que despejava água num barril, com a inscrição sou útil inda brincando. Essa estátua fora roubada tempos depois, quando então o governo anunciou que "quem quisesse fazer outro igual e mais barato se apresentasse na administração das obras públicas" ${ }^{14}$ A estátua foi refeita, desta vez com sobras do encanamento da cidade, em chumbo, e ainda hoje se encontra no local.

O Passeio Público terminava em um grande terraço, pavimentado com mármores de diversas cores, construído acima do nível do resto do jardim e debruçado sobre o mar, que naquela época se estendia até ali. Local de apoteose para o caminhante que percorria o passeio desde sua entrada, ao longo de seu eixo principal, esse terraço impressionava com sua beleza a quem por ali passava. Segundo Charles de Ribeyrolles, viajante francês que por ali passou em 1859, "o terraço do Passeio Público, em noites de verão, quando o céu se reclama de estrelas, é superior aos balcóes de Veneza, a todos os jardins de Granada, sem excluir os dos reis mouros" $^{15}$

(12) MACEDO, Joaquim M. de. op. cit., p. 62.

(13) Idem, p. 62.

(14) Ibid. P. 69

(15) BANDEIRA, Manuel, ANDRADE, Carlos Drummond de. (org.). Rio de Janeiro em prosa e verso. Rio de Janeiro: José Olympio, 1965. p. 85. 


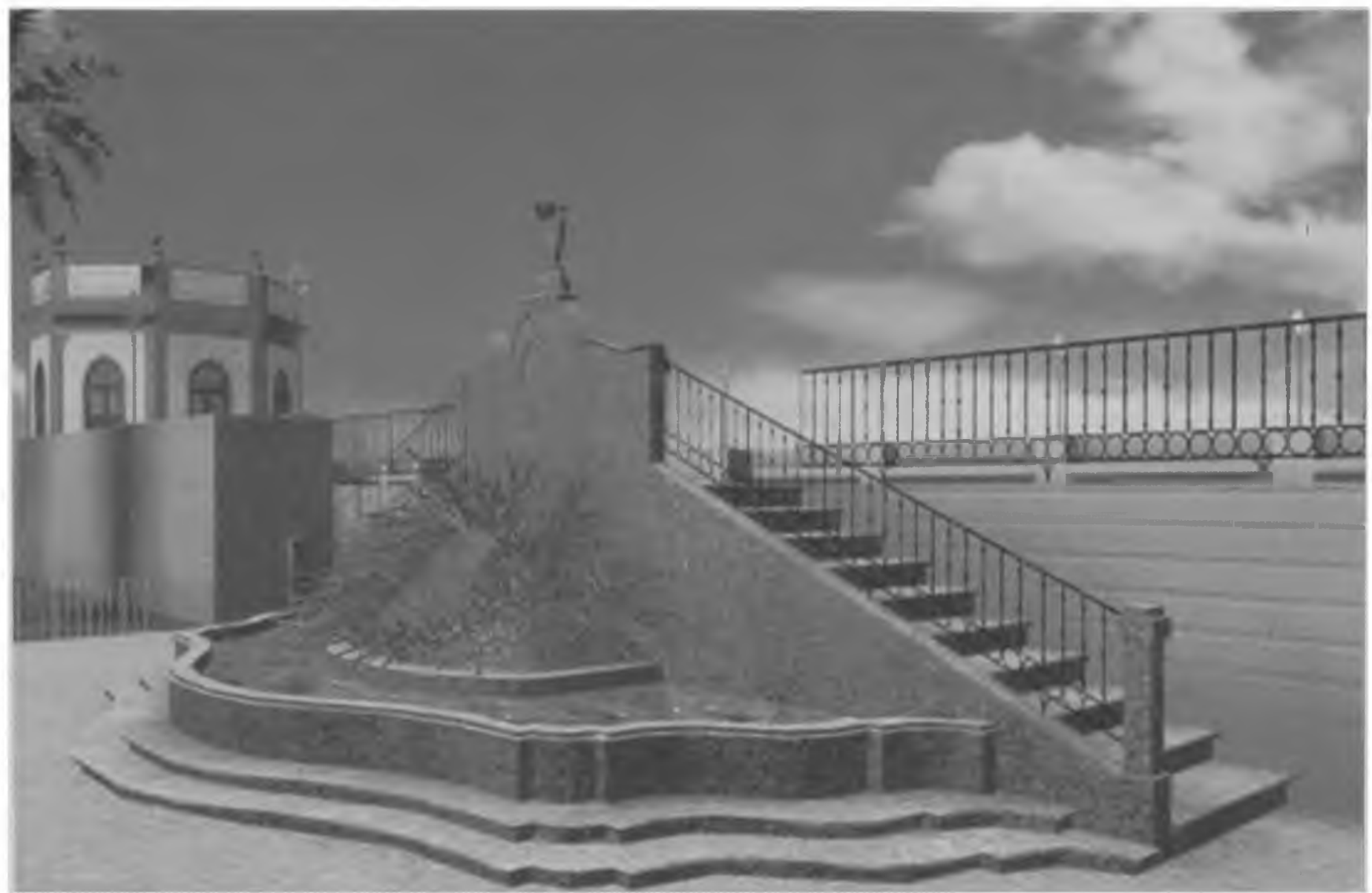

Figura 7: O "outeiro", mais conhecido como a Fonte dos Amores, de mestre Valentim: reconstrução virtual Fonte: Autor

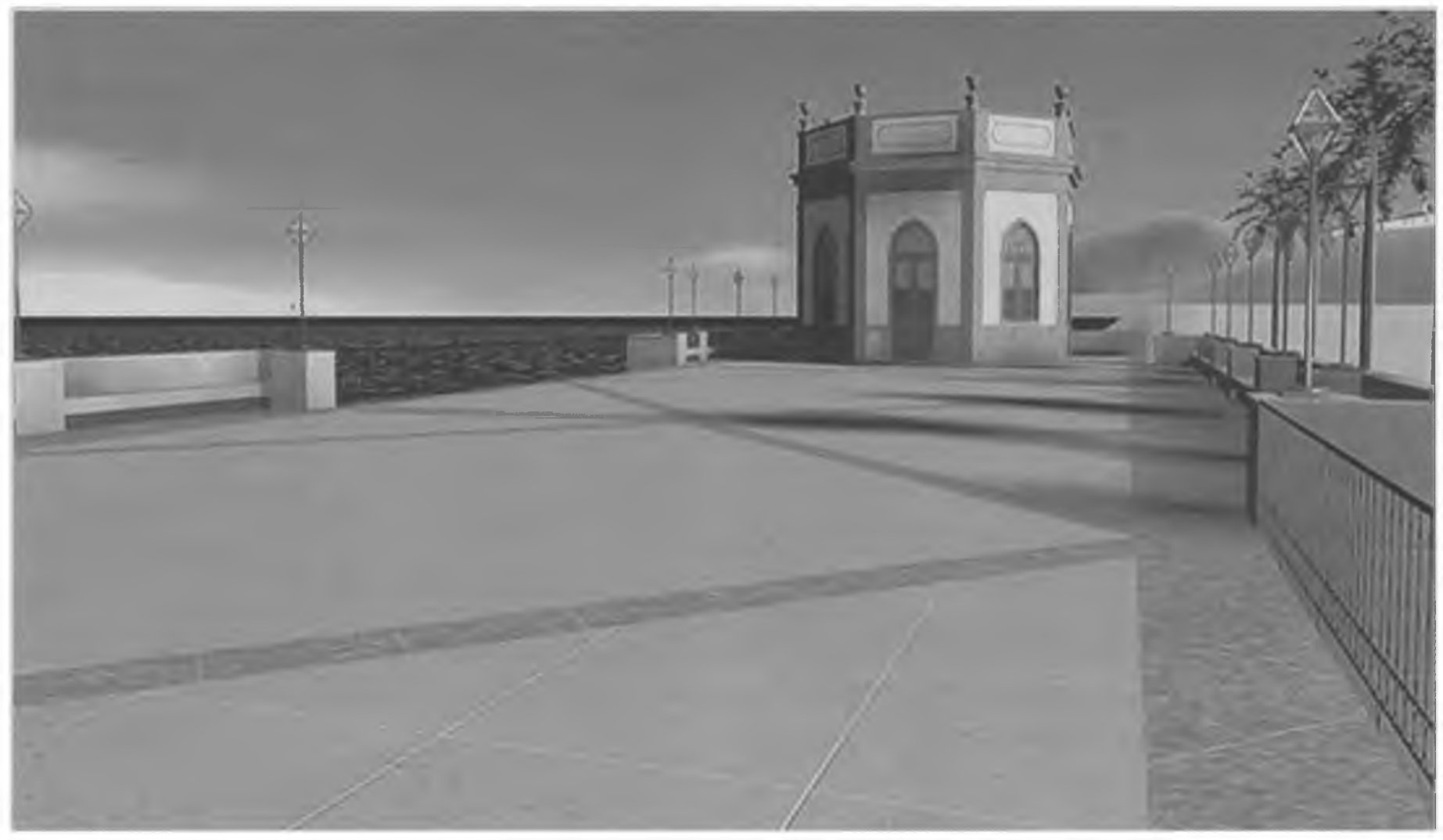

Figura 8: $O$ antigo terraço do passeio debruçado sobre o mar Fonte: Autor

\section{Paisagem} Ambiente Ensaios 


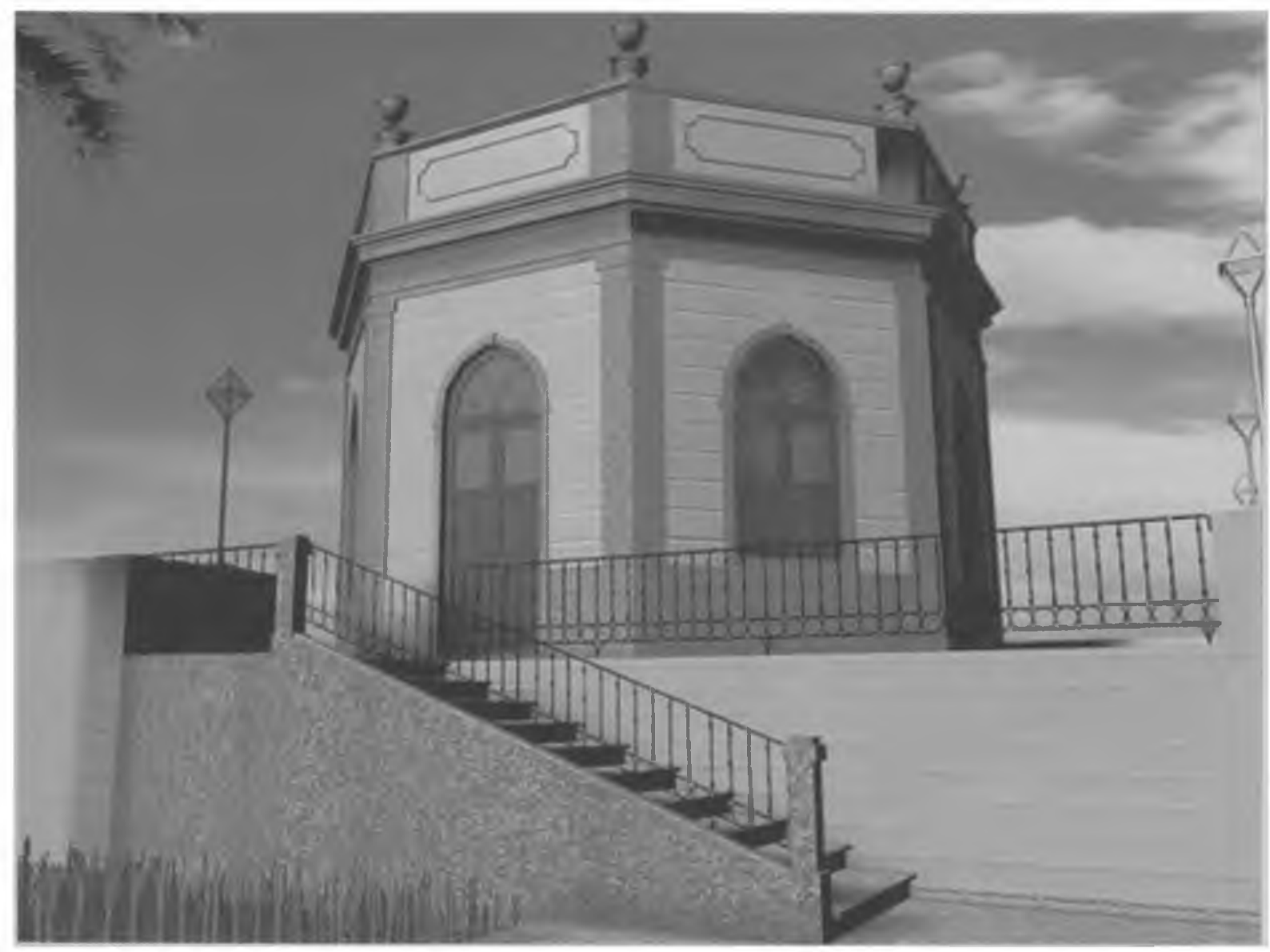

Figura 9: Um dos antigos pavilhôes do terraço: reconstituição a partir de antigas gravuras $e$ fotografias

Fonte: Autor

\section{Breve Análise Espacial}

Ao nos depararmos com a concepção original do Passeio Público, pode-se perceber de imediato o traçado retilíneo e geométrico imaginado por mestre Valentim, dominado pela existência de dois eixos básicos estruturadores daquele espaço, ortogonais entre si, "deixando bèm no centro do jardim e no meio do seu correr um limitado terreiro quase circular" ${ }^{16}$ O eixo que atravessa o jardim, ligando o portão ao espaço da Fonte dos Amores, demonstra notadamente mais força, sobrepujando em importância àquele que o corta ortogonalmente.

(16) MACEDO, Joaquim Manuel de. op. cit., p. 61

São Paulo n. 13 p. $97 \quad 124$ dez. 2000




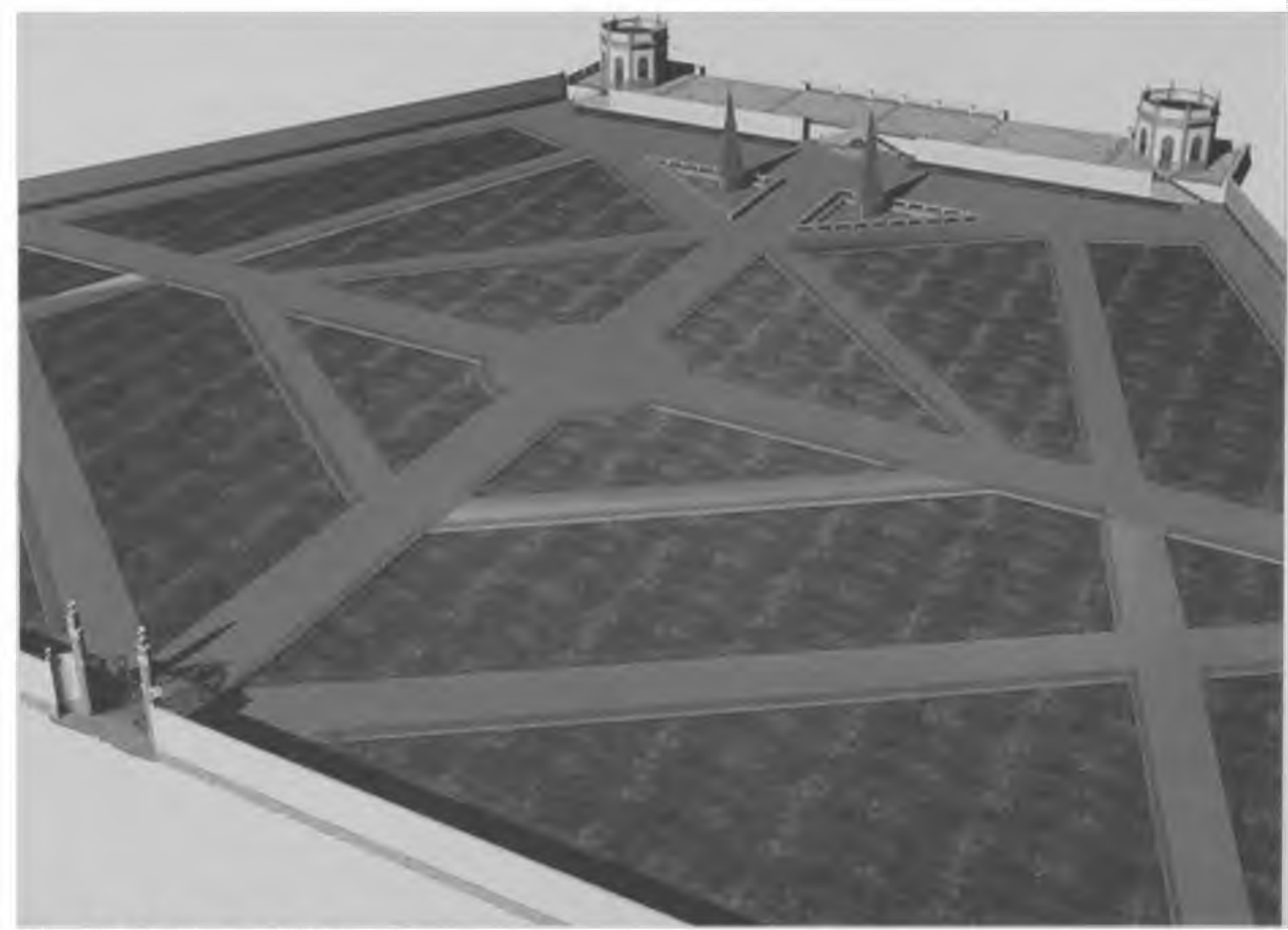

Figura 10: O espaço do jardim

Fonte: Autor

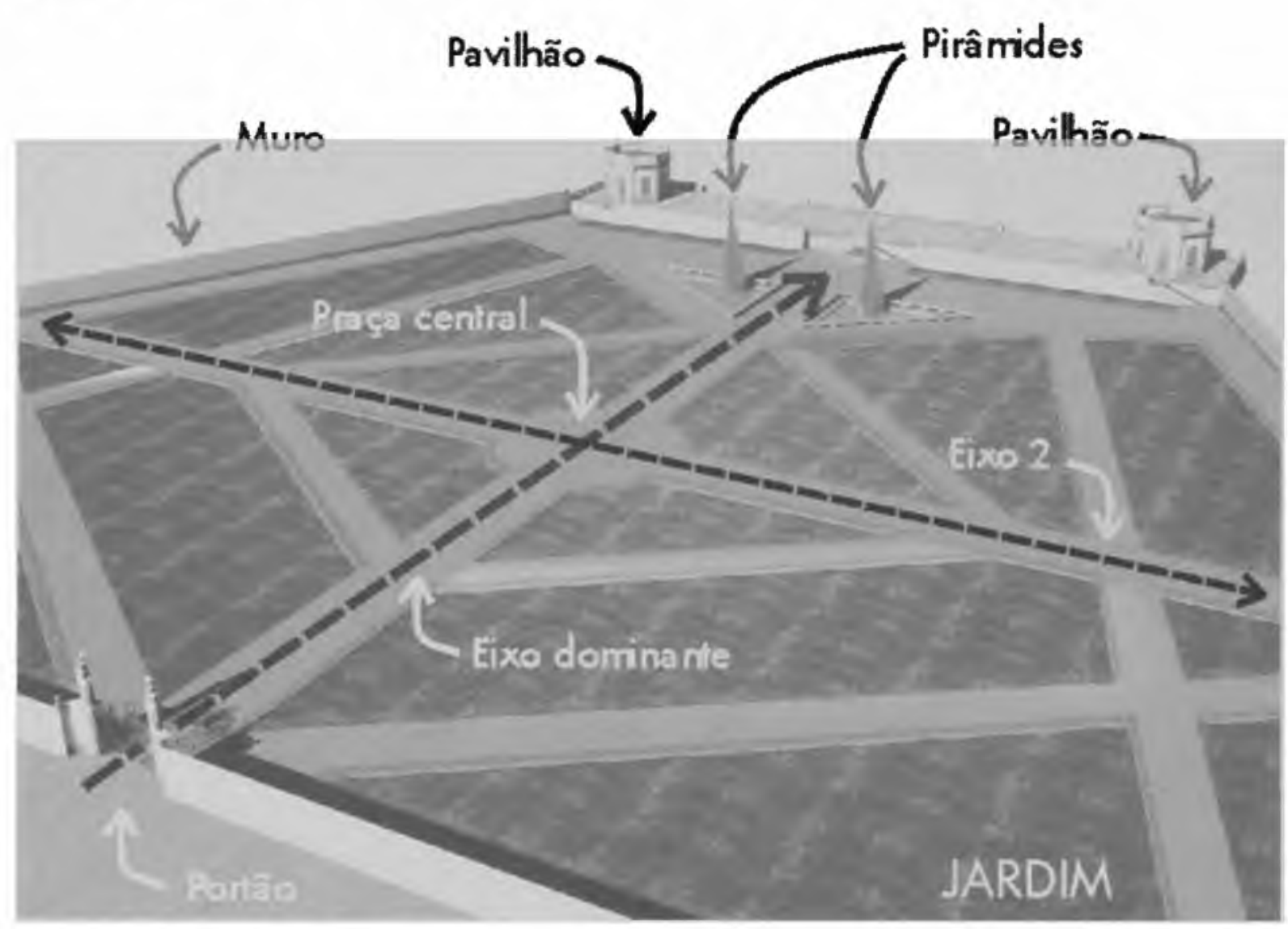

Figura 10a: Análise do espaço

Fonte: Autor 
Ao final do eixo dominante, encontramos um espaço diferente daquele do jardim. Agora, percebe-se que os caminhos cessam de existir, e "um largo espaçoso se fazia ver, (.../ e um pouco mais para o centro mostravam-se dois pequenos lagos artificiais, do meio de cada um dos quais erguia-se uma pirâmide de cantaria" ${ }^{17}$ À frente desse cenário encontra-se, perfeitamente alinhada ao eixo dominante, a Fonte dos Amores, "o mais belo triunfo de Mestre Valentim $^{\prime 18}$

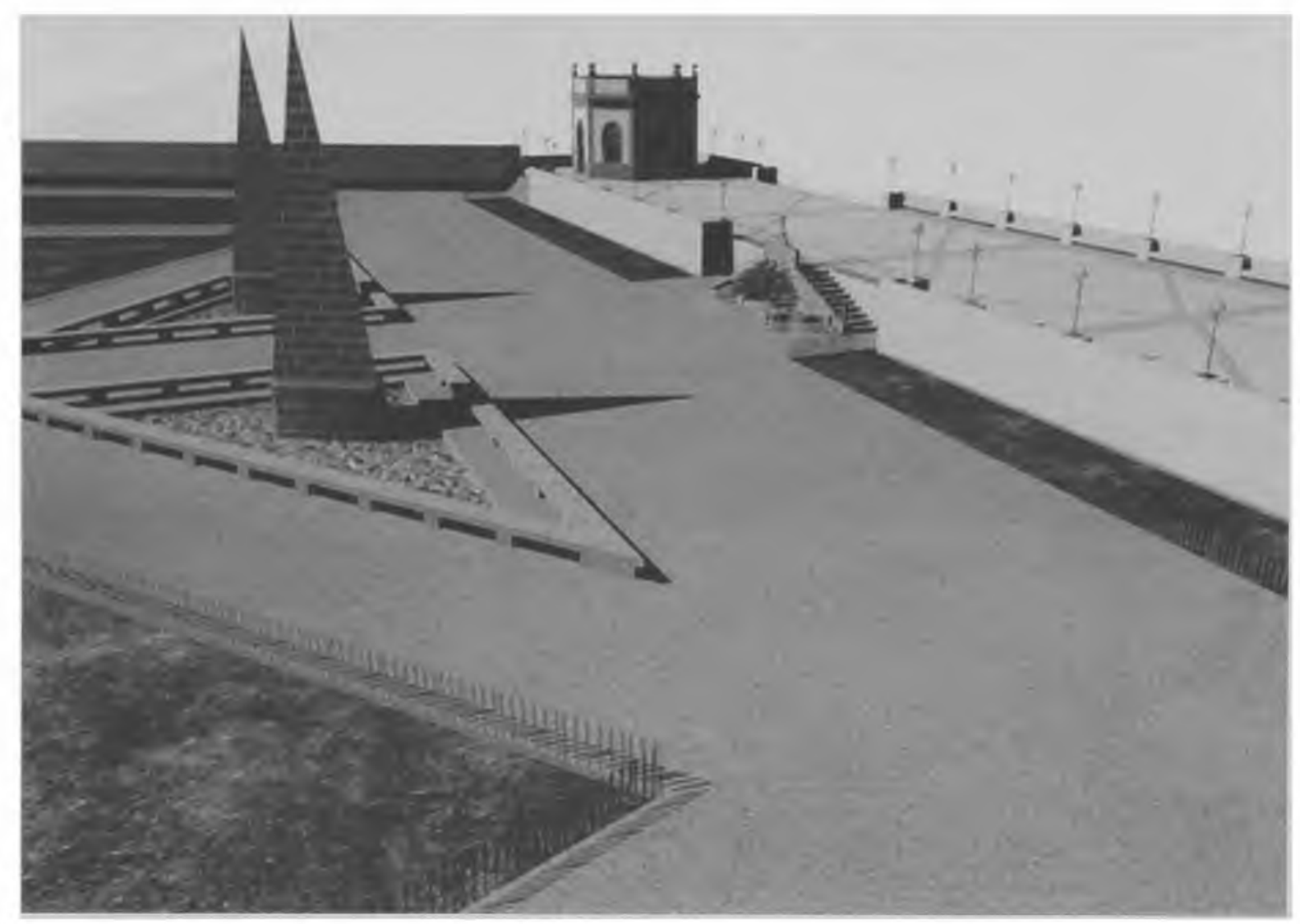

Figura 11: O espaço da Fonte dos Amores Fonte: Autor

Logo após esse espaço, pode-se perceber a existência de um outro espaço contíguo, em que o passeio terminava debruçando-se sobre o mar. O terraço do Passeio Público, contendo os dois pavilhões, era um dos lugares mais apreciados do Rio antigo, por sua beleza e encantamento, de onde se descortinava um belíssimo panorama da baía de Guanabara e, em noites claras, uma inesquecível visão do céu estrelado.

(17) Idem, p. 62.

(18) Ibid., p. 62. 


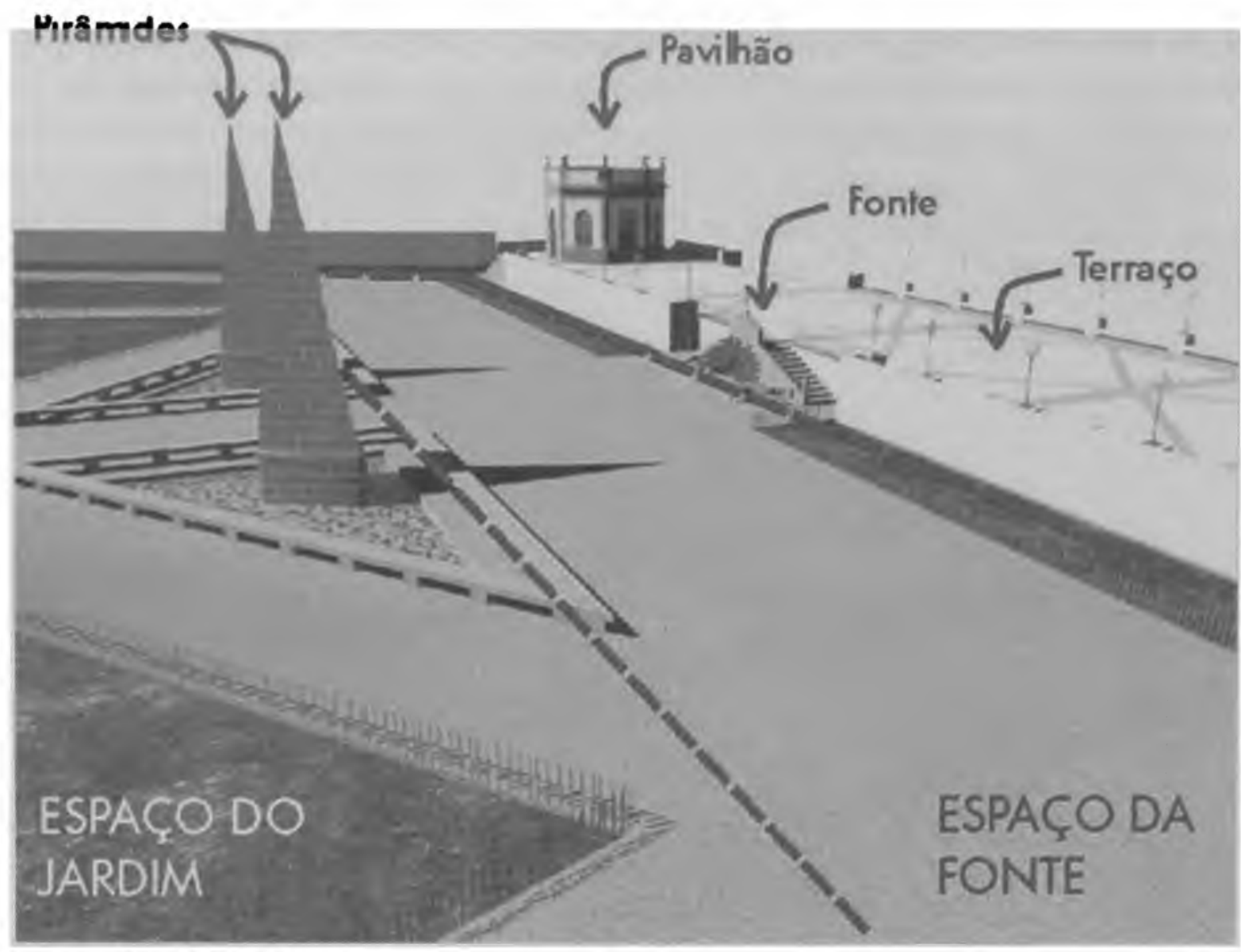

Figura 1la: Análise do espaço

Fonte: Autor

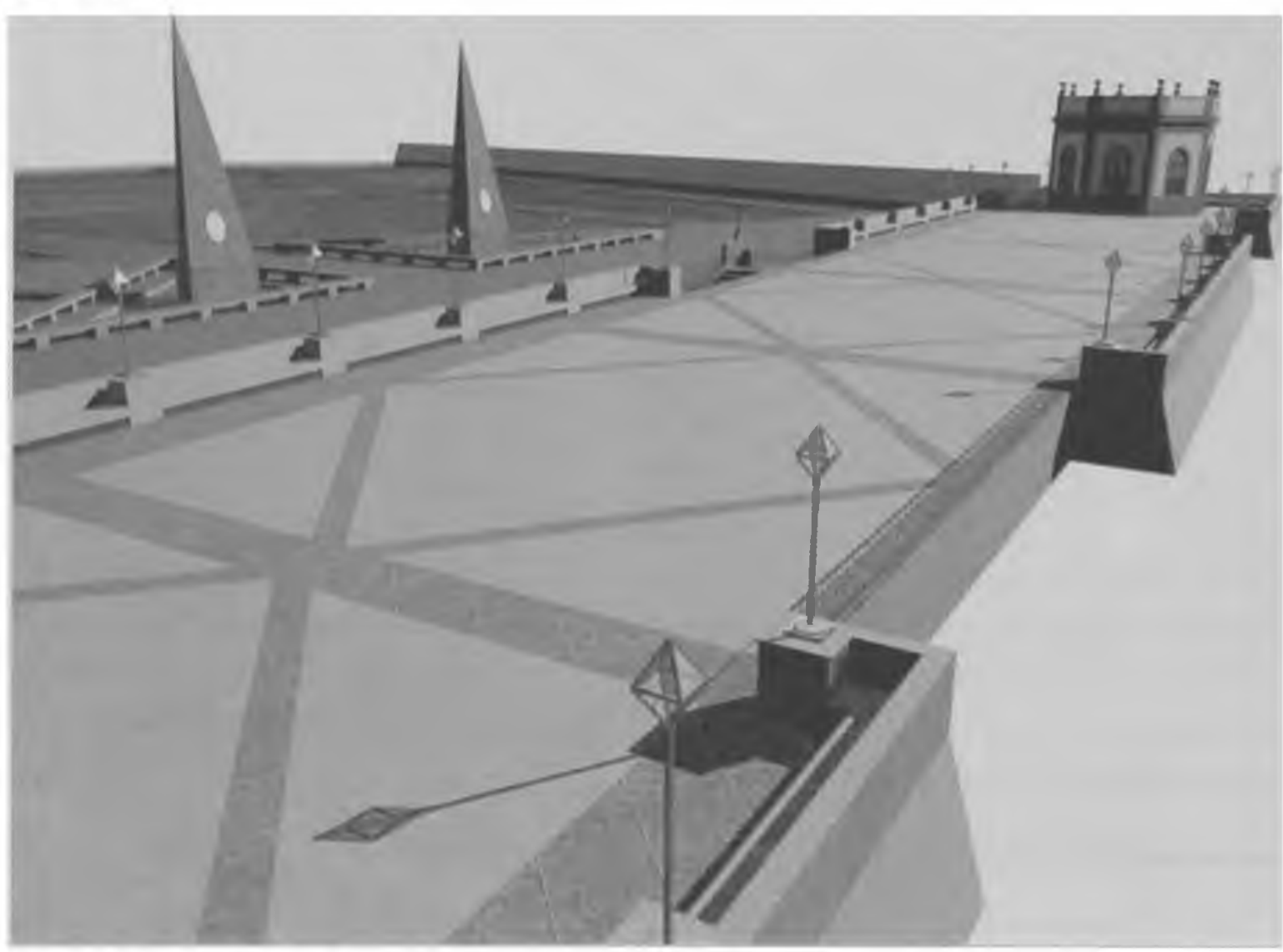

Figura 12: O espaço do terraço Fonte: Autor

112 Paisagem São Paulo n. 13 p. 97124 dez. 2000 Ambiente Ensaios 13 


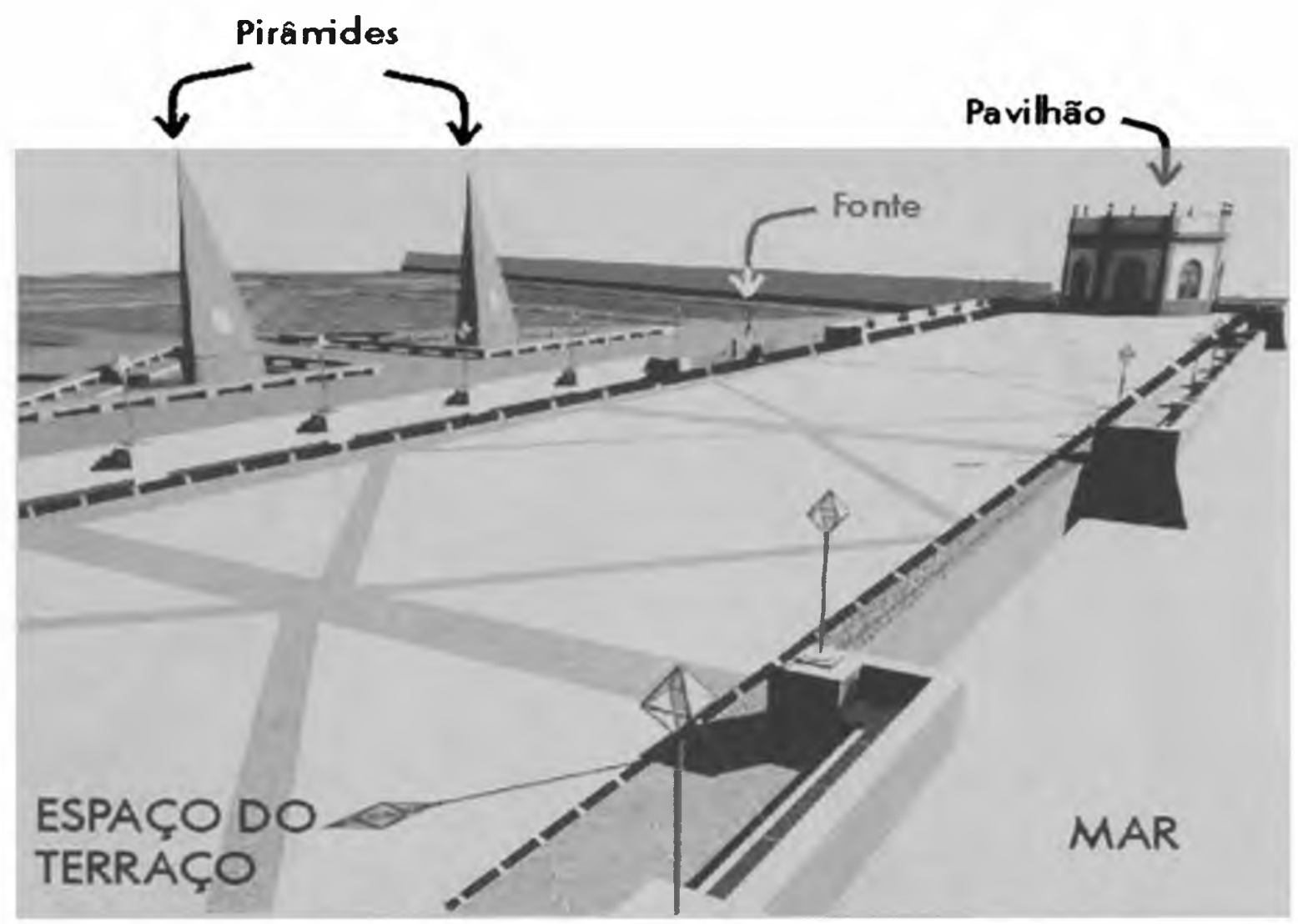

Figura 12a: Análise do espaço

Fonte: Autor

Todos esses diferentes espaços existentes no interior do Passeio Público se reforçam em suas características, na medida em que se constata que, originalmente, existia um muro cercandoos. De fato, "pelos três lados que olhavam para a terra, o Passeio Público era fechado por um alto muro /.../ mais notável pela sua robustez do que pela graça, que, aliás, devia ter ${ }^{\prime 19}$ Assim, tal muro atua como um elemento de secção, destacando-o de seu entorno, fazendo com que funcionasse quase como um universo próprio, desligado das coisas que ocorriam do lado de fora. Deste modo, ao transpassar o portão do passeio, mergulhava-se em um mundo encerrado em si próprio, em que toda a experiência espacial ali vivenciada não sofria qualquer influência do exterior, intensificando-se gradualmente até o momento de seu clímax - o terraço debruçado sobre o mar.

Assim, pode-se resumir o espaço total do Passeio Público de mestre Valentim de acordo com a articulação sucessiva de seus diferentes espaços que, mesmo coexistindo lado a lado, apresentam valores intrínsecos absolutamente diversos, da seguinte forma:

\section{PORTÃO $\Rightarrow$ "JARDIM" $\Rightarrow$ FONTE $\Rightarrow$ IERRAÇO" $\Rightarrow$ MAR}

(19) Ibid., p. 61. 


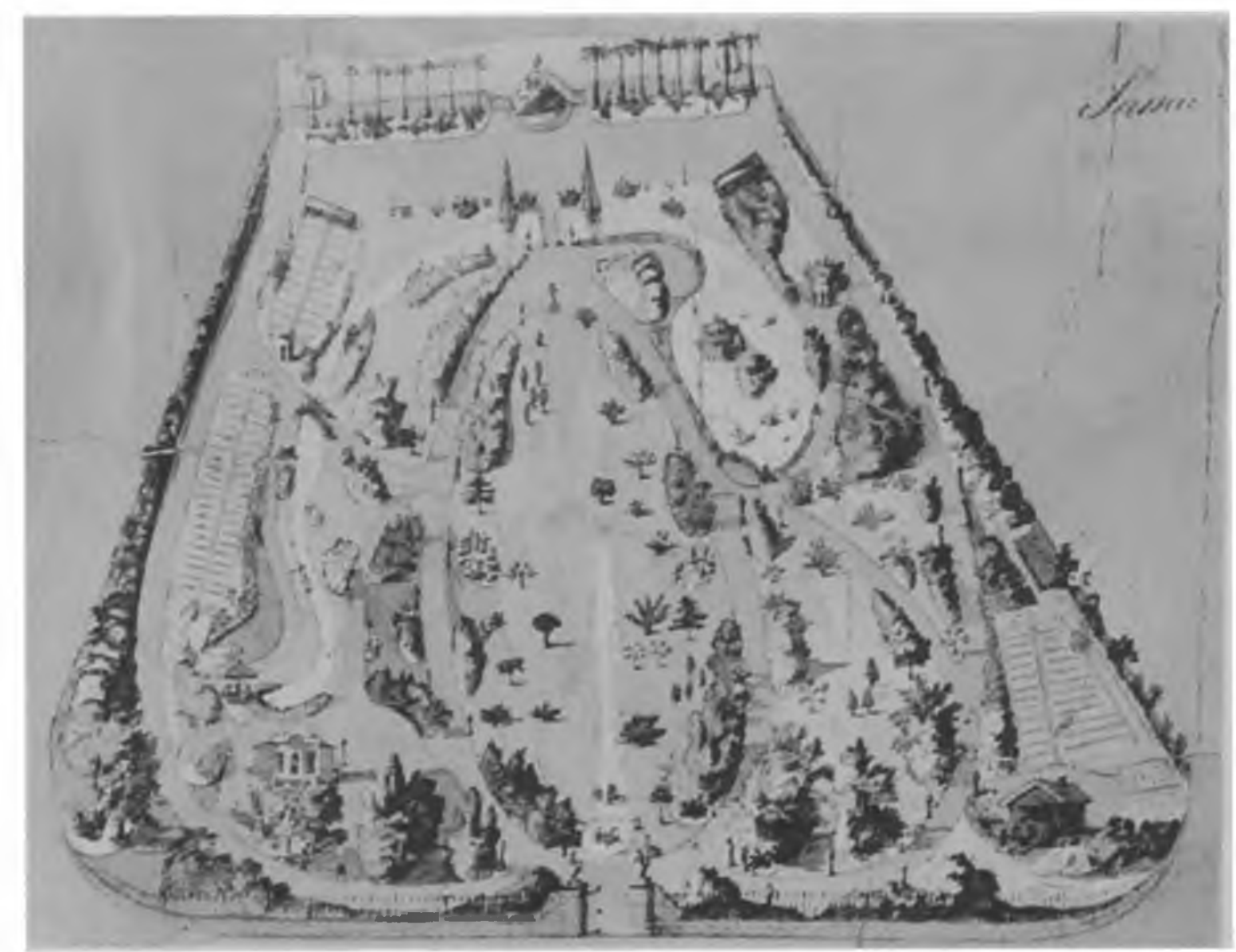

Figura 13: Planta original da reforma do Passeio Público, em aquarela do próprio Glaziou Fonte: MACEDO, Joaquim N. de. op. cit., p. 128-129

Passava da metade do século e a imprensa da capital, fazendo eco aos apelos do público, clamava por reformas no passeio, em lastimável estado de conservação. Em 1860, a visita do arquiduque Maximiliano da Áustria à cidade, inesperadamente, foi o motivo que faltava para a administração pública fazer a reforma que tantos queriam.

Conta-nos Joaquim Manoel de Macedo que o arquiduque, em visita aos jardins do Passeio Público, subiu ao terraço para apreciar a tão comentada vista que se tinha daquele espaço. "Mas, ah! Mal tinha o arquiduque avançado quatro passos no recinto da elegante varanda, $e$ já com ambas as mãos levava o lenço ao nariz. O nosso vexame foi tão grande que um brado geral soou, e o governo não teve remédio senão acordar e olhar para o Passeio Público. "20

D. Pedro II, então, resolveu confiar o serviço de remodelação do local ao tabelião Francisco José Fialho, homem de conhecida reputação na cidade, que, por sua vez, contrata o paisagista e arquiteto francês Auguste François Marie Glaziou (1833-1906).

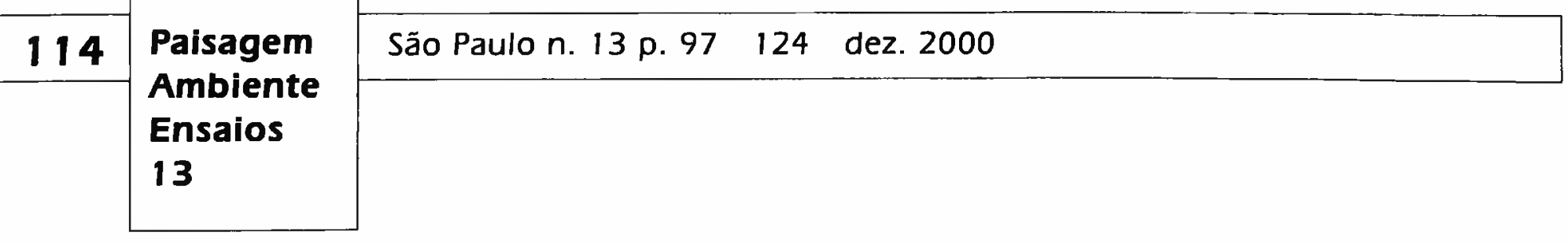


As obras de remodelação tiveram início em 1861, sendo inauguradas pelo imperador no dia 7 de setembro de 1862, ainda incompletas. O gradil a substituir o muro que dava para a rua do passeio, sobre base de granito, não fora fundido a tempo, sendo improvisado tapumes de madeira para o fechamento. Por falta de recursos, as faces laterais do Passeio Público não puderam receber o novo gradil, mantendo-se os antigos muros com aberturas espaçadas. Aproveitou-se para recuar o alinhamento em cerca de seis metros, alargando a rua do passeio e sacrificando parte da área original do jardim.

Glaziou remodelou completamente o traçado do jardim, tendo inclusive que retirar árvores originais, que não se adaptariam aos novos caminhos. Seguindo sua composição romântica, cria novos caminhos serpenteados, entrecortados por lagos com uma ilhota artificial, agora povoados com peixes e aves aquáticas. Constrói ainda um "botequim de arquitetura grega, em cuja frente se abre um largo com mesas e cadeiras, tendo do lado um coreto" ${ }^{21}$ e uma casa que serviria de residência aos funcionários do jardim, inclusive a dele próprio, agora nomeado diretor dos parques e jardins da Casa Imperial, ambos posteriormente demolidos.

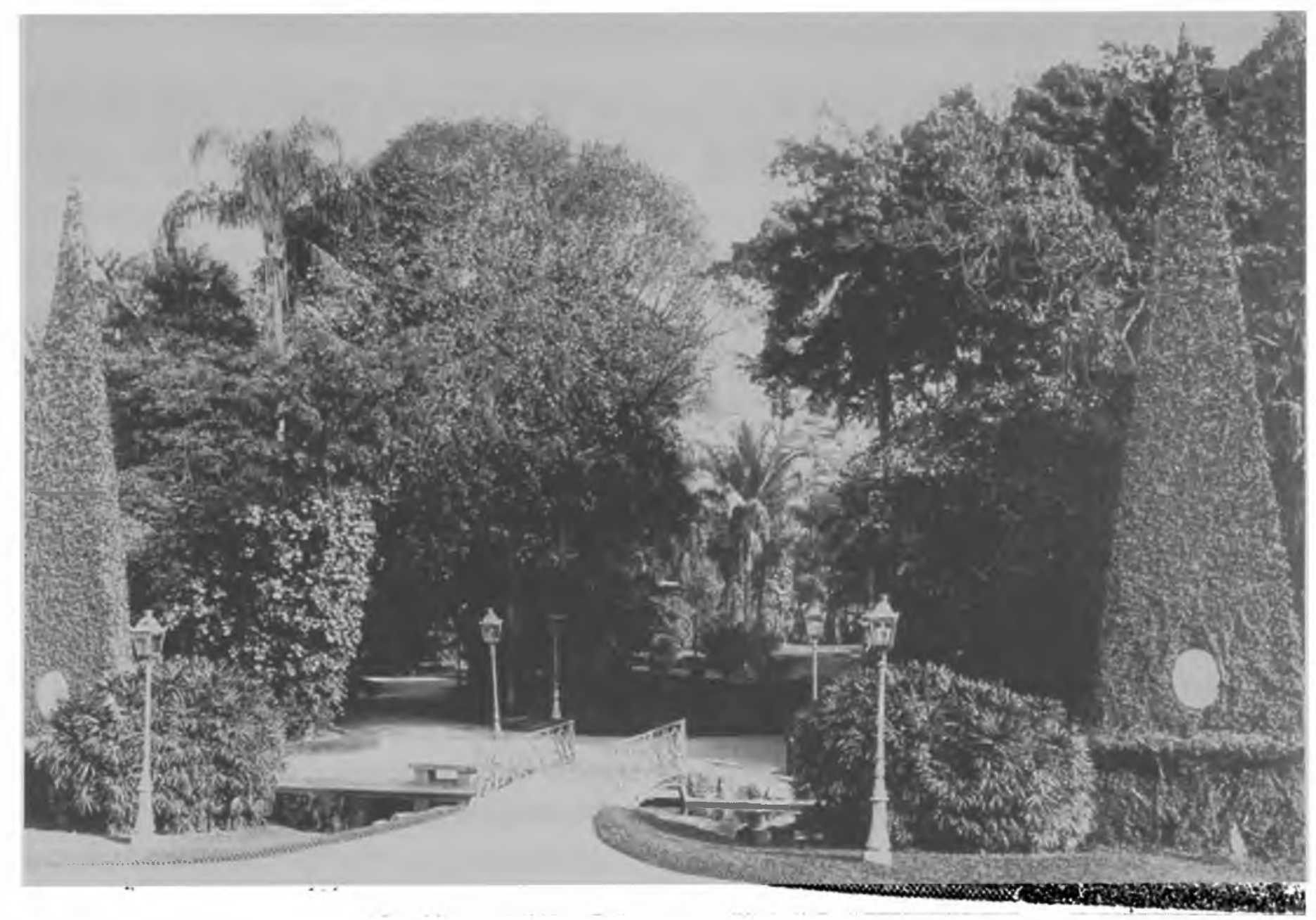

Figura 14: Aspecto das pirâmides de mestre Valentim dentro da concepção romântica de Glaziou. Foto de 1904 Fonte: Augusto Malta (AGCRJ)

(21) AMARAL, Dr. Alexandrino F. do, SILVA, Dr. Ernesto dos Santos. Consolidação das leis e posturas municipais. Rio de Janeiro, 1905. Ia parte. p. 571.

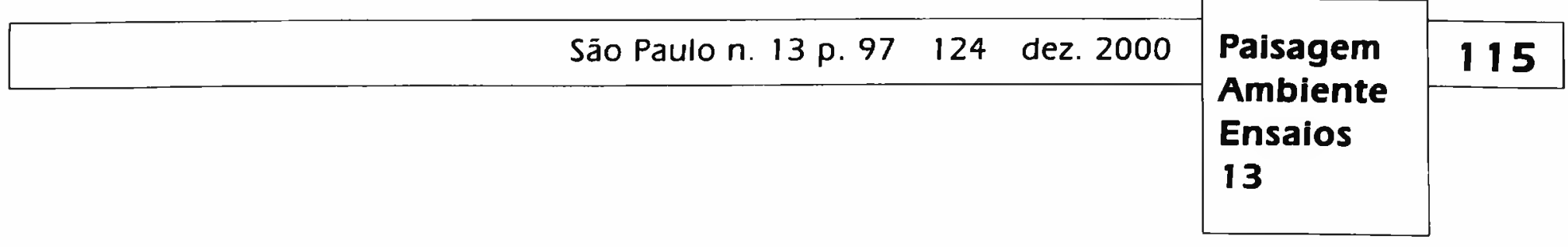


Em seu livro de 1862 sobre a cidade, Manuel Duarte Moreira de Azevedo (1832-1903) descreve o novo Passeio Público: "(...) vê-se um jardim lindo e de agradável perspectiva; (...) em vez da disposição geométrica, da simetria monótona que até então era seguida em todos os jardins, vêem-se ruas curvar unindo-se umas às outras, tabuleiros de grama de diversa extensão e feitio com maciços de flores e arbustos, e de espaço em espaço sobre a relva árvores destacadas, ou reunidas constituindo um denso bosque. É um jardim paisagista, no qual não predominam, como outrora no antigo Passeio, o cordel do jardineiro, o compasso do cálculo e da simetria, porém a linha curva, a variedade, a imitação da natureza de um modo elegante e gracioso, não como ela é, mas como deverá ser (...)" 22

Glaziou traz consigo da França profissionais especialistas na imitação da madeira e da pedra, chamados de "cascateiros", artistas especializados na arte de fingir, como se falava na época. Ainda antes da vinda de Glaziou, a técnica da imitação dos materiais já existia entre nós desde o final do século 18, segundo nos conta José Marianno Filho. Segundo ele, "os cascateiros franceses, exímios fabricantes de cascatas artificiais (Campo de Sant'Anna) criaram o gênero de imitar árvores e pedras. Aliás, durante todo o século XIX a arte de 'fingir' foi muito do agrado do povo. Havia 'fingidores' de madeira, de mármore, e sobretudo, de pedra "23

É interessante fazermos uma pequena comparação das impressões deixadas pelas reformas implementadas por Auguste Glaziou, pelas análises feitas por autores diversos que tratam sobre o espaço em questão.

Moreira de Azevedo, cujo texto data de 1862, ano de inauguração das obras, elogia a reformulação do espaço, onde vê "um jardim belo e agradável." Em relação ao antigo traçado de mestre Valentim, nos conta que "outrora apresentava regularidade nas ruas, no plantio das ánores, uma disposição geométrica, uma simetria monótona, que se notava em todos os nossos jardins" ${ }^{24}$

Joaquim Manoel de Macedo, que escreveu seu livro Um passeio pela cidade do Rio de Janeiro durante as obras de remodelação, e teve acesso à planta do projeto de Glaziou, enaltece o novo Passeio Público, fazendo ainda uma pequena exposição sobre a maneira que um novo profissional, o "jardineiro-paisagista" concebe seus espaços. Segundo ele, "o olhar do artista $e$ a ciência da botânica são os grandes instrumentos deste trabalho. Esse olhar que nivela o terreno, (...), que cria nele claros-escuros, divaga por muitas vezes por muito longe dos limites fixados ao lugar de sua obra; (...) cobiça os panoramas longínquos, (...), liga-os pela arte no jardim que deste modo parece muito maior, ilimitado mesmo" ${ }^{25}$

(22) AZEVEDO, Manuel Duarte Moreira de. Pequeno panorama do Rio de Janeiro. Rio de Janeiro, 1862. p. 142.

(23) MARIANNO FILHO, José. O Passeio Público do Rio de Janeiro (1779- 1783). Rio de Janeiro: A Noite, 1943, P. 42.

(24) AZEVEDO, Manuel Duarte Moreira de. op. cit. p. 143.

(25) MACEDO, Joaquim Manuel de. op. cit. p. 74.

\section{Paisagem}

Ambiente

Ensaios

13

São Paulo n. 13 p. 97124 dez. 2000 
A descrição que Macedo faz consegue captar, de maneira bastante precisa, as características presentes na concepção romântica dos jardins, no qual o artista procura reproduzir em um espaço limitado, e de maneira racional, as relaçōes pictóricas (pitorescas) existentes, de forma selvagem, na natureza.

Macedo demonstra certa preocupação com o sacrifício de algumas árvores originais do passeio, àquela altura quase centenárias. Porém, admite que tal atitude é preferivel "à mutilação do plano do jardim e o abandono dos preceitos de perspectiva, que de tão essencial importância se mostram em obras dessa ordem ${ }^{26}$

De acordo com esses dois cronistas, contemporâneos às reformas do passeio, podemos verificar a atitude de agradável aceitação da nova concepção do Passeio Público. A estética romântica para o novo traçado do jardim é aceita como um fator de modernidade para a cidade, ainda mais quando trazida por um profissional francês, substituindo o passado colonial "atrasado", representado pelo jardim de mestre Valentim. Assim, o passeio público tornar-seia um jardim paisagista, "admitido em todo o mundo como o mais natural, o mais livre, e que produz mais agradáveis e completas ilusôes" ${ }^{27}$

José Marianno Filho, em seu texto datado de 1943, revela-nos uma outra opinião. Ligado a outro contexto ideológico, nacionalista, Marianno não vê com bons olhos a reformulação de Glaziou. Em relação à derrubada das árvores, diz ele que Glaziou, "com o mais profundo desprezo pela tradição da cidade, (...) devastou completamente o jardim, para sobre os destroços da área desmatada delinear um novo traçado ondulante $(. . .)^{\prime 28}$

Ainda de acordo com suas idéias, ciente dos textos de Macedo e de Moreira de Azevedo, cita as preocupações passadas sobre a derrubada das árvores originais. Porém, segundo ele, "já naquela época distante, havia o tradicional desprezo pelas coisas do passado" ${ }^{29}$

Nota-se aqui a inversão da atribuição dos valores em relação à questão do "passado nacional" que, enquanto à época da reforma do passeio era desprezado, em nome de uma "modernidade" importada, na época de José Marianno, em um momento de valorização ufanista de nossos valores nacionais, esse passado é novamente descoberto, sendo desprezado justamente aquele modelo importado de outrora.

Termina então José Marianno: "Oue mal teria feito à civilização brasileira a preservação integral de um maravilhoso parque umbroso e pitoresco, construído ingenuamente à moda da terra, fora da influência postiça de outros povos? (...) Os autores desse atentado se dizem civilizados, e acoimam de retrógrados os passadistas. "30

(26) Idem, p. 75

(27) Ibid. p. 74.

(28) MARIANNO FILHO, José. op. cit., p. 42

(29) Idem, p. 42.

(30) Ibid. p. 43 


\section{Breve Analise Espacial}

Ao analisarmos a reforma romântica do passeio implementada por Glaziou, percebe-se, a princípio, a profunda modificação realizada no jardim pelo paisagista. De fato, ao abandonar completamente a concepção geométrica e racional de mestre Valentim, Glaziou interfere no espaço do jardim, a fim de transformá-lo em algo conceitualmente diferente, com características românticas, coerente com sua linguagem de trabalho e de acordo com os ditames da "modernidade" na época.

À primeira vista, pode-se supor que tal reforma romântica transforma inteiramente os espaços do Passeio Público, visto que concepções tão díspares certamente gerariam espaços absolutamente diversos. Porém, analisando-se esses espaços em função da percepção do espaço ali vivenciada, pode-se entender que sua articulação básica, ilustrada abaixo, não é modificada.

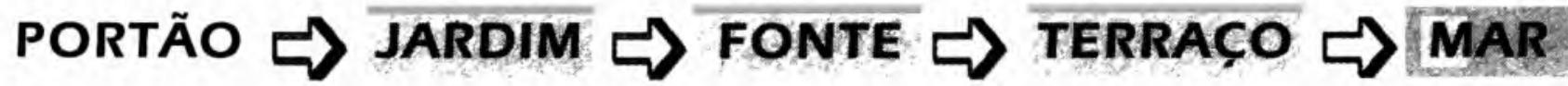

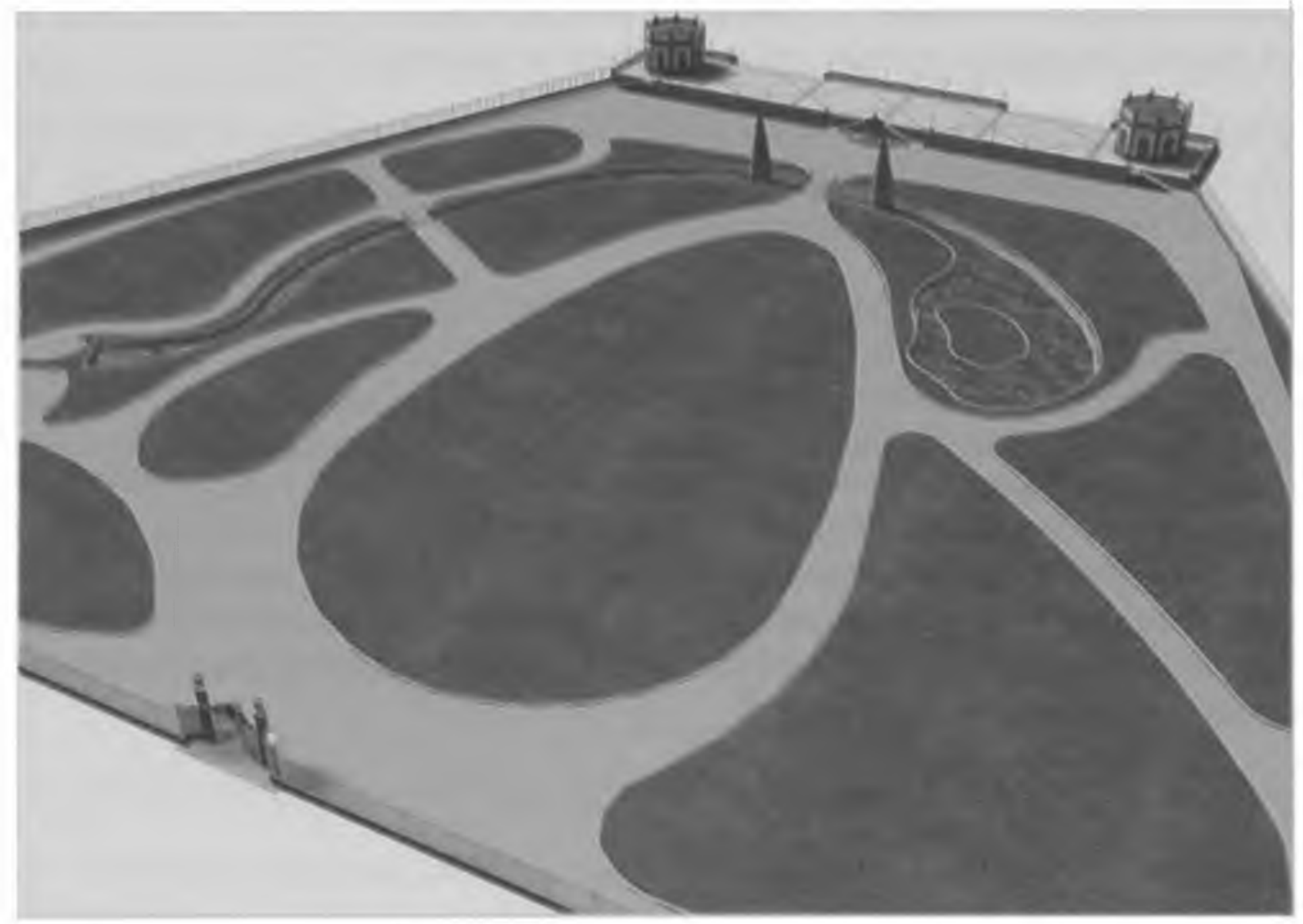

Figura 15: O espaço do jardim na concepção romântica de Glaziou

Fonte: Autor 


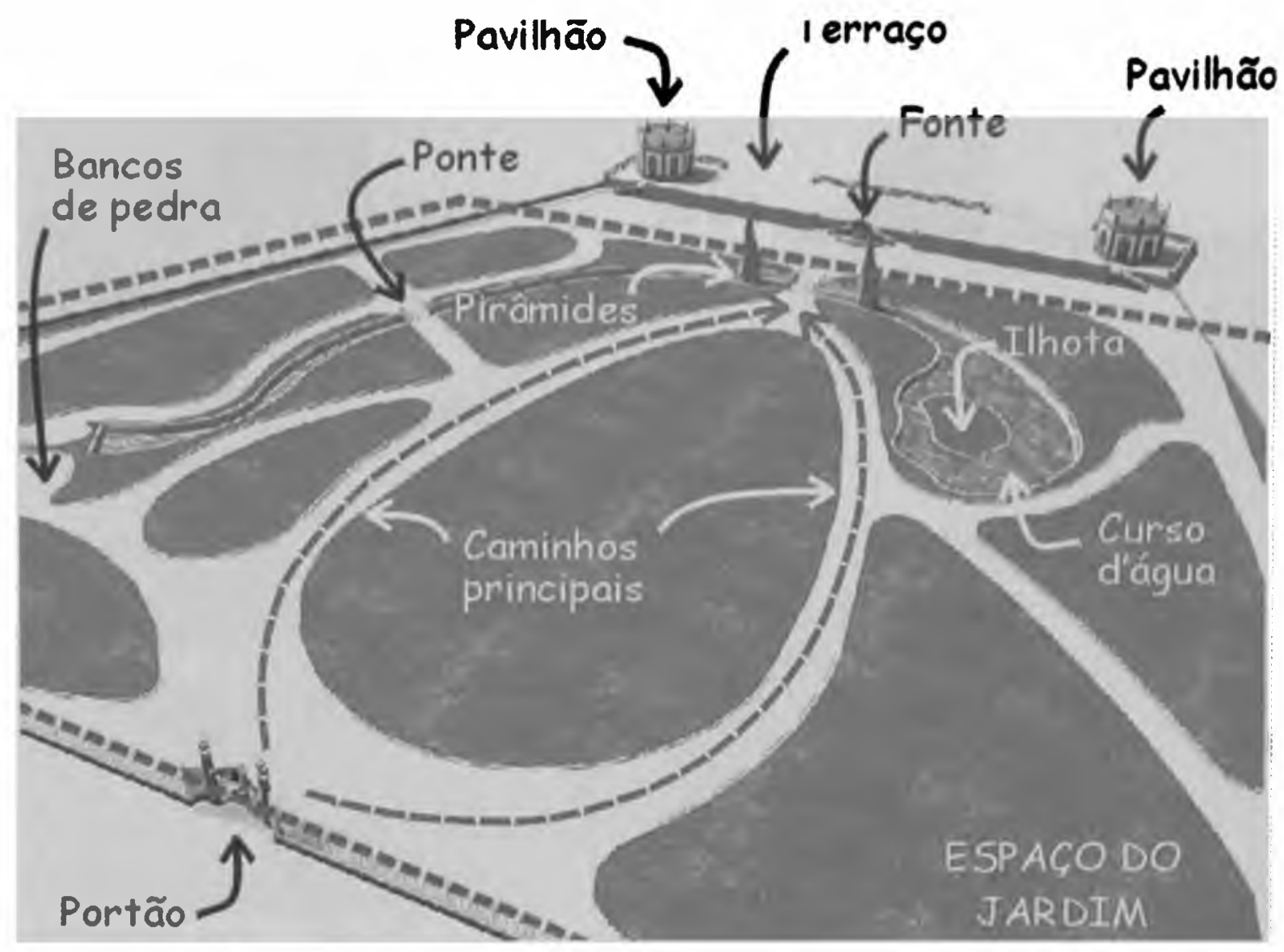

Figura 15a: Análise do espaço. Nota-se a substituição da antiga perspectiva por caminhos curvos e sinuosos que levam à fonte Fonte: Autor

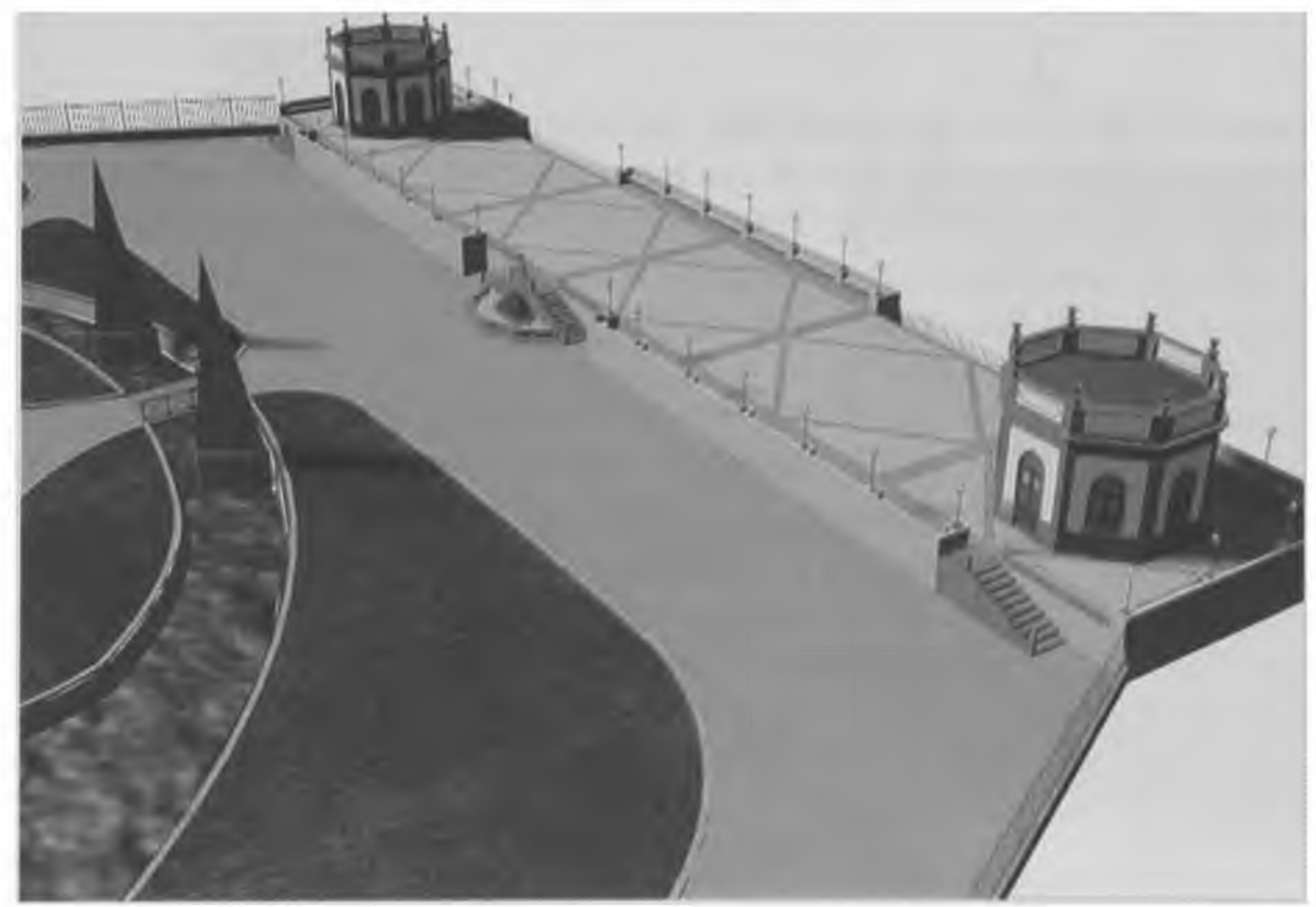

Figura 16: O espaço da Fonte dos Amores Fonte: Autor 


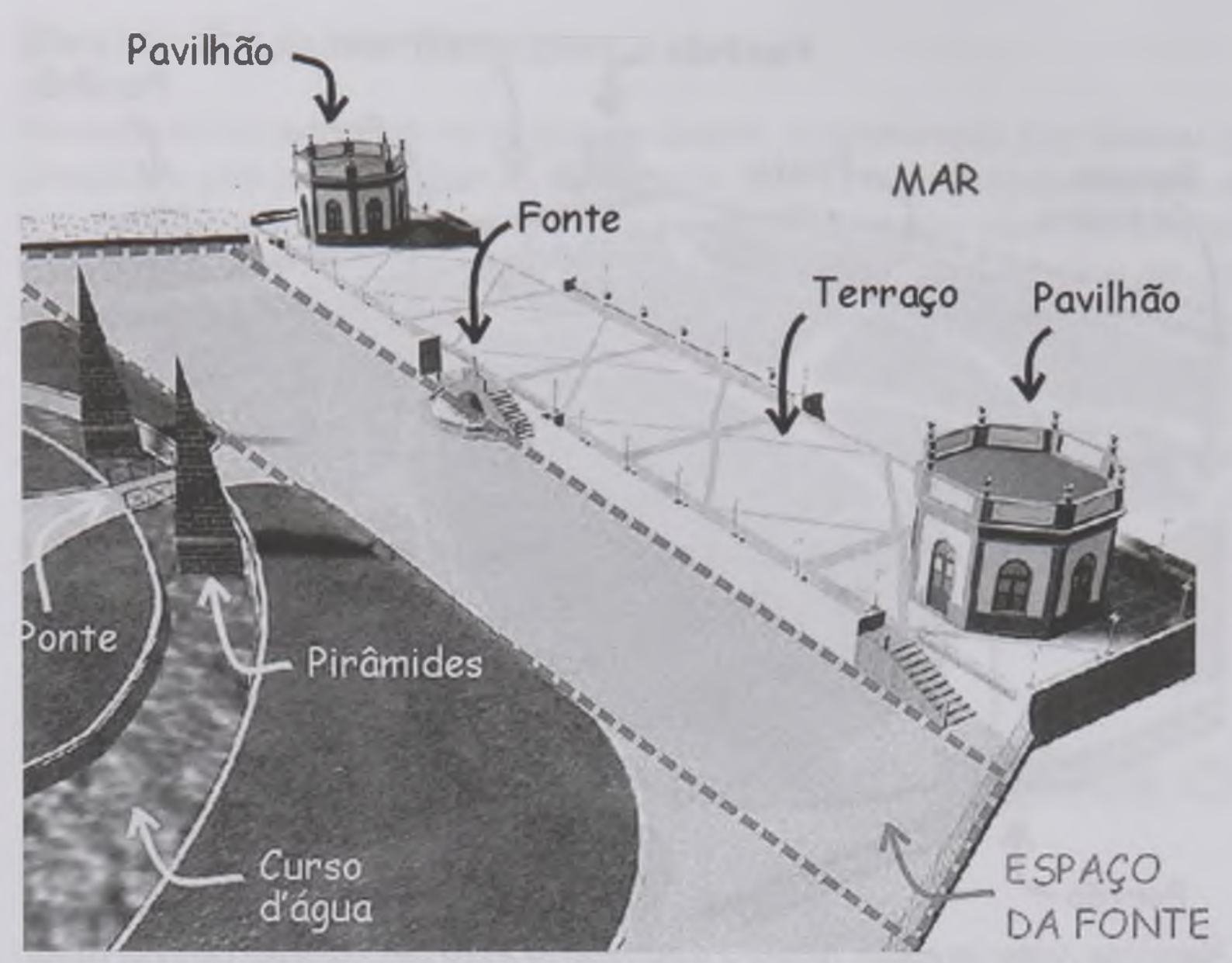

Figura 16a: Análise do espaço

Fonte: Autor

Auguste Glaziou, na reforma de 1861, concentra-se somente em intervir no espaço do jardim, "romantizando-o", não sendo de sua intenção a intervenção nos espaços da fonte e no do terraço. Segundo Joaquim M. de Macedo, "M. Glaziou, o inteligente e hábil jardineiro, tece os maiores louvores àquele bem acabado trabalho de nosso Valentim e, especialmente, admira o primoroso grupo dos jacarés [a Fonte dos Amores]" ${ }^{31}$.

Assim, ao manter a relação de seus espaços inalterada, o espaço do jardim, mesmo transformado, ainda possui um caráter essencialmente dinâmico, cuja função básica é a de conduzir o freqüentador do jardim para o espaço da Fonte dos Amores e, conseqüentemente, para o clímax espacial proporcionado pelo terraço debruçado sobre o mar. Deste modo, a experiência espacial vivenciada no jardim é inteiramente transformada, influenciada e enriquecida agora pelos conceitos românticos ali coerentemente aplicados. Contudo, em sua totalidade, mantém-se a mesma.

(31) MACEDO, Joaquim Manuel de. op. cit., p. 74. 


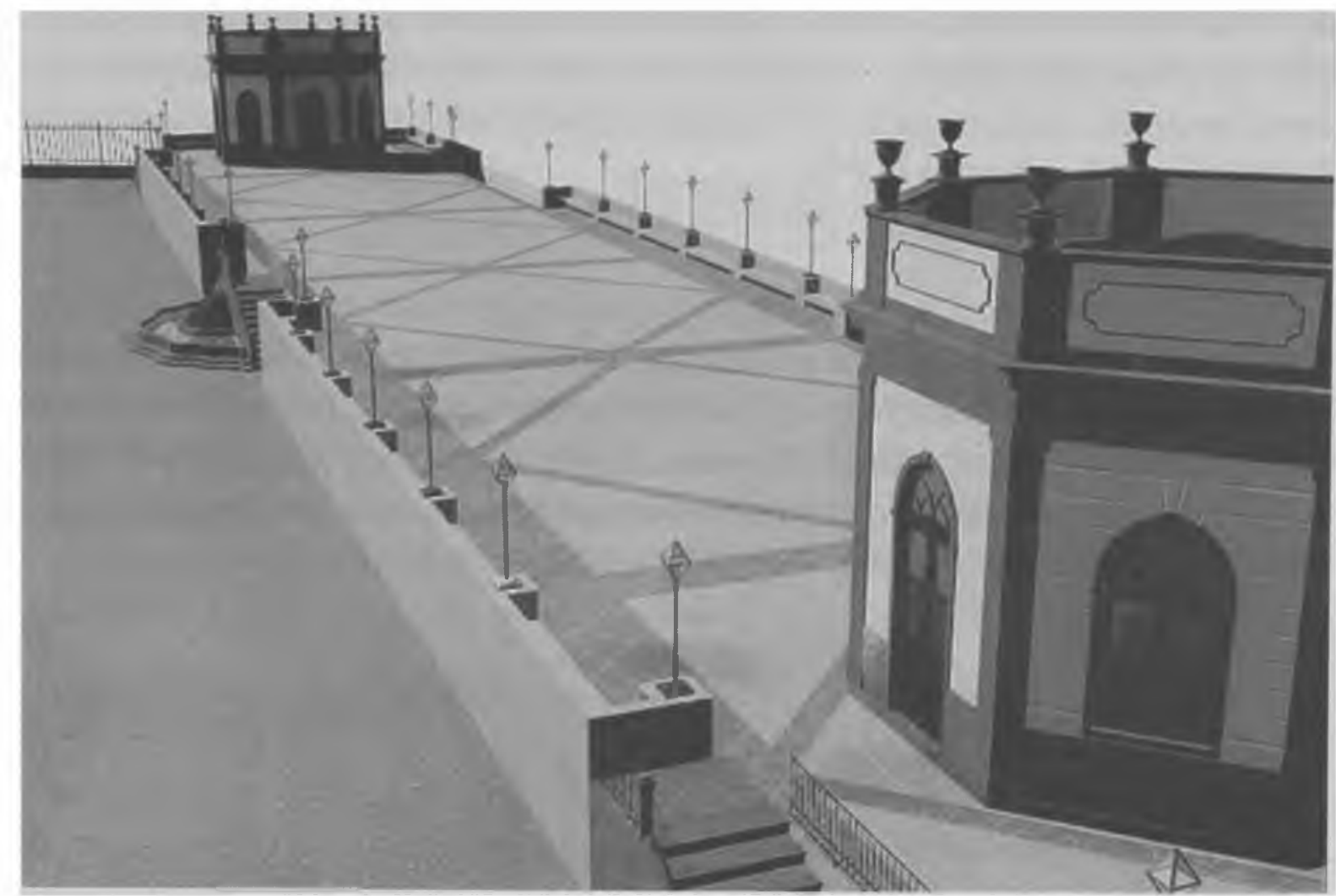

Figura 17: O espaço do terraço

Fonte: Autor
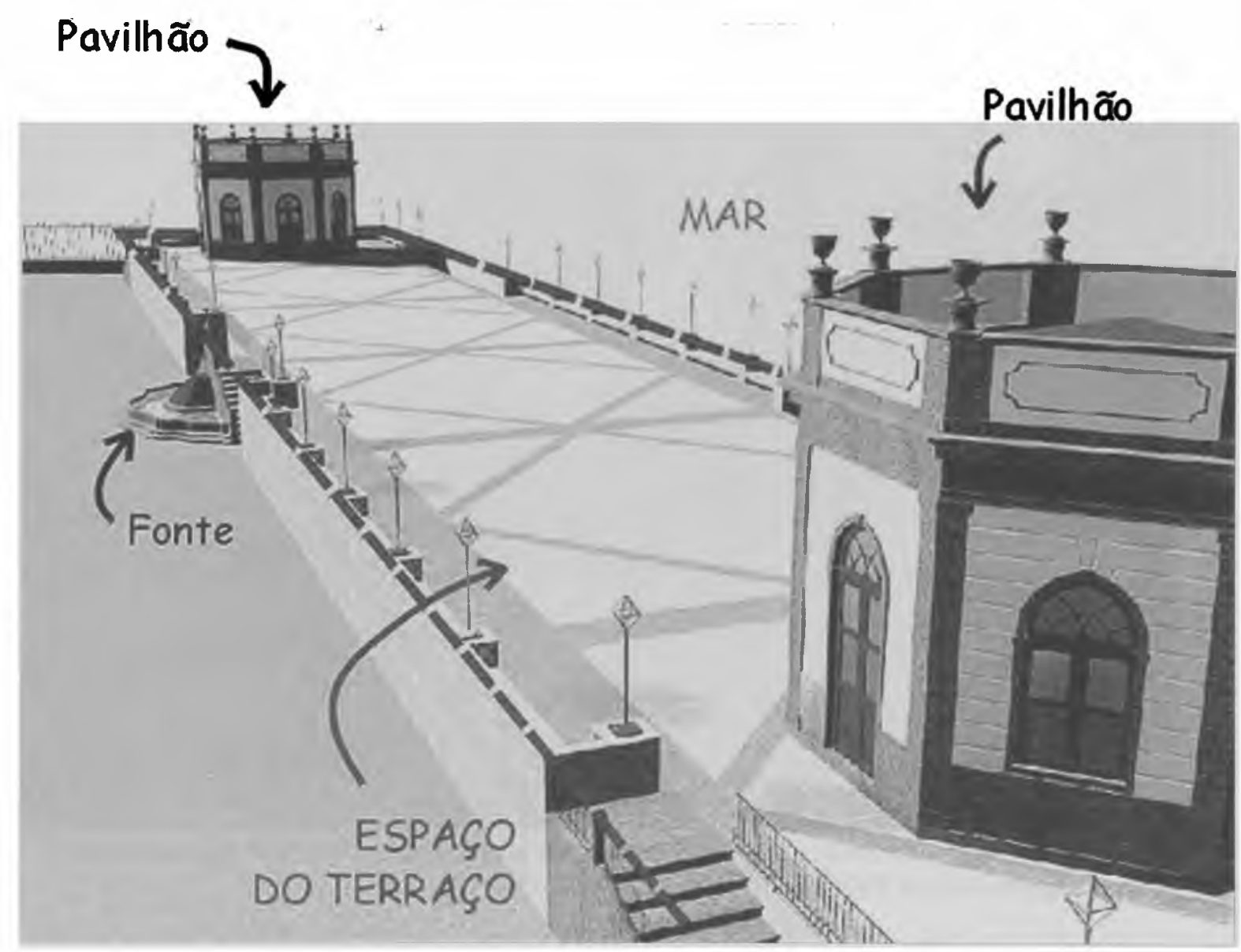

Figura 17a: Análise do espaço

Fonte: Autor 
Portanto, visto por esse enfoque, tal constatação permite-nos contradizer as observações feitas por José Marianno Filho, em seu livro sobre o Passeio Público, segundo o qual, "foi preocupação do paisagista Glaziou destruir o que fora feito. Se não conseguiu de todo, não foi certamente de boa vontade..." 32 , mais adiante, afirma que "o paisagista francês devastou completamente o jardim (.../"133

\section{Conclusão}

Com a construção da avenida Beira-Mar, na primeira década do século, o passeio sofre sua primeira profunda modificação. Apesar de somente interferir nos valores espaciais inerentes ao terraço, nota-se que a experiência espacial que existia já se modificou irreversivelmente. De fato, ao ascender para o terraço, o observador não mais vivencia o impacto visual oferecido por tal espaço. Desse modo, pode-se resumir a articulação dos espaços do passeio neste momento da seguinte forma:

\section{PORTÃO $\Rightarrow$ JARDIM $\Rightarrow$ FONTE $\Rightarrow$ CASSINO $\Rightarrow$ AVENIDA $\Rightarrow$ MAR}

Assim, como pode ser observado na fotografia abaixo, a partir desse momento o terraço se dissocia do Passeio Público, passando a fazer parte da avenida Beira-Mar como um espaço de estar sem muita razão de existir. Essa constatação é confirmada quando se verifica que nessa ocasiāo são colocadas grandes gradis entre o espaço da fonte e o terraço para controlar o acesso do público ao jardim pela nova avenida. Percebe-se que, a partir de então, o Passeio Público nunca mais será o mesmo.

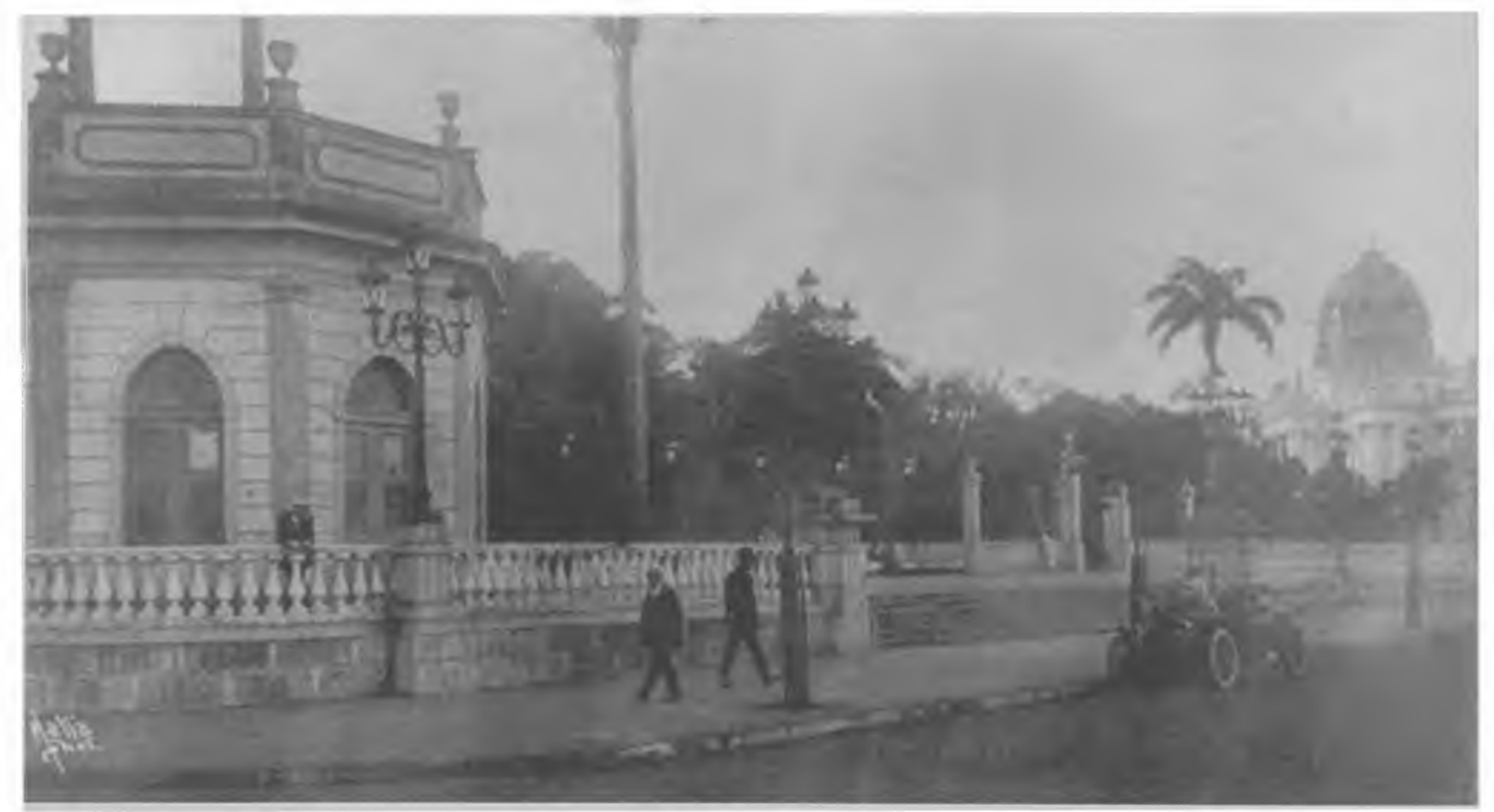

Figura 18: O espaço do terraço, com a construção da avenida Beira-Mar, näo mais pertence ao Passeio Público Fonte: Augusto Malta (AGCRJ)

(32) MARIANNO FILHO, José. op. cit., p. 40.

(33) Idem, p. 42.

122 Paisagem Ambiente Ensaios 13 São Paulo n. 13 p. $97 \quad 124$ - dez. 2000 
Porém, é com a construção do cassino Beira-Mar que o Passeio Público passa pelo período que mais esteve desfigurado em relação à sua conceituação original. Construído, como já visto, sobre o terraço e de fundos para o jardim, o cassino Beira-Mar toma seu lugar na articulação total de seus espaços, que passa a ser entendida da seguinte forma:

\section{PORTÃO $\Rightarrow$ JARDIM $\Rightarrow$ FONHE $\Rightarrow$ CASSINO $\Rightarrow$ AVENIDA $\Rightarrow$ MAR}

Essa desfiguração do Passeio Público também foi percebida na época, como pode ser lido em uma reportagem da Revista da Semana, datada de 16 de abril de 1921. Segundo tal reportagem, escrita antes de sua construção, "agora, o Passeio Público, no lindo sítio em que ainda existe o seu terraço antigo, outr'ora debruçado sobre o mar, vae ter um restaurante envidraçado, cujos planos o sr. Prefeito Carlos Sampaio acaba de escolher, embora com algumas restriçôes. (...)

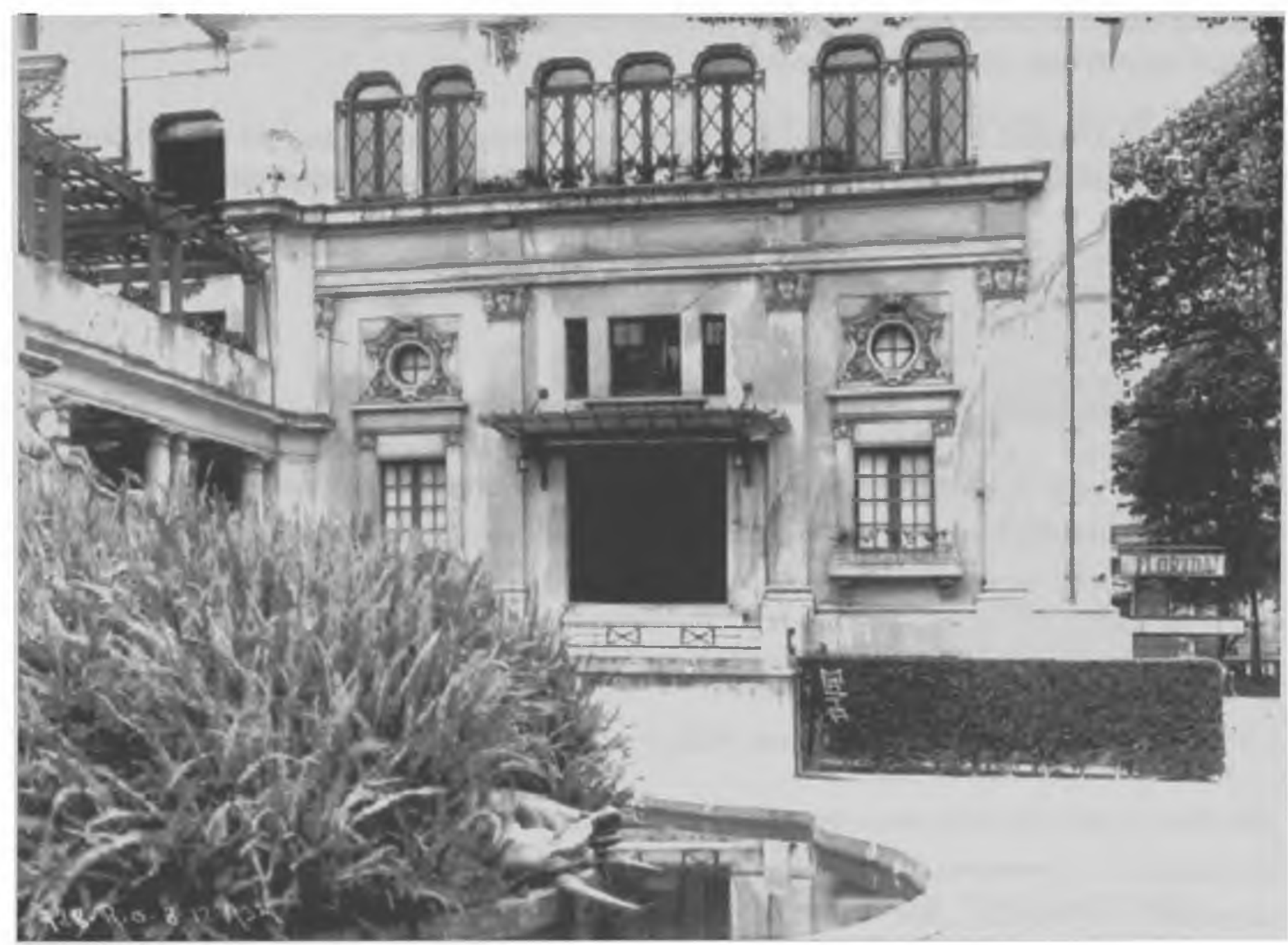

Figura 19: O cassino Beira-Mar, construído sobre o terraço do passeio. Em primeiro plano, a Fonte dos Amores de mestre Valentim

Fonte: Augusto Malta (AGCRJ)

É possível que os novos aspectos do jardim tradicional venham corresponder às exigências da cidade, na sua marcha vertiginosa para a innovação. (...) 
Mas o desaparecimento do terraço, que primitivamente se debruçava sobre o boqueirão do Passeio, é um golpe decisivo no velho e histórico logradouro decorado por Mestre Valentim da Fonseca e Silva, quando tão fácil teria sido restaurá-lo como uma relíquia do século XVIII, considerando-o como uma jóia antiga engastada no Rio moderno (...)"

Mesmo com a posterior demolição do cassino, o Passeio Público não escaparia de ser atingido pelo avassalador crescimento de nossa cidade ao longo deste século. A partir da década de 60 , com a construção do Aterro do Flamengo, o passeio é definitivamente afastado do mar, fazendo com que sua concepção original se perca para sempre.

Apesar da constatação inevitavelmente "romântica" de que o crescimento e o progresso de nosssa sociedade foram os responsáveis pela destruição do conceito original existente no Passeio Público, entende-se que a cidade se apresenta em constante transformação e que, excetuando-se os casos protegidos por eventual tombamento, tais modificações ao longo do tempo apresentam-se de forma inevitável.

Atualmente o Passeio Público do Rio de Janeiro, mesmo desprovido de sua concepção original, ainda serve de refúgio para quem busca um pouco de sombra e sossego naquela região da cidade.

Esse seu objetivo, pelo menos, se manteve intacto ao longo do tempo.

\section{Bibliografia}

AZEVEDO, Manuel Duarte Moreira de. Pequeno panorama do Rio de Janeiro. Rio de Janeiro, 1862.

BAKER, Geoffrey H. Análisis de la forma. Trad. Santiago Castán. Barcelona: Gustavo Gili, 1991.

BANDEIRA, Manuel, ANDRADE, Carlos Drummond de. (org.). Rio de Janeiro em prosa e verso. Rio de Janeiro: José Olympio, 1965.

BURMEISTER, Hermann. Viagem ao Brasil através das províncias do Rio de Janeiro e Minas Gerais. São Paulo: Livraria Martins, 1952.

CARVALHO, Anna Maria Monteiro de. O Passeio Público e o chafariz das Marrecas de Mestre Valentim. Gávea. Rio de Janeiro: PUC-RJ, n. 7, dez. 1989.

EBEL, Ernst. O Rio de Janeiro e seus arredores em 1824. Sāo Paulo: Nacional, 1972.

GUINSBURG, J. O romantismo. São Paulo: Perspectiva, 1978.

LEITHOLD, T. Von, RANGO, L. Von. O Rio de Janeiro visto por dois prussianos em 1819. Sāo Paulo: Nacional, 1966.

MACEDO, Joaquim M. de. Um passeio pela cidade do Rio de Janeiro. Rio de Janeiro: Garnier, 1991.

MARIANNO FILHO, José. O Passeio Público do Rio de Janeiro (1779-1783). Rio de Janeiro: A Noite, 1943.

MIDDLETON, Robin, WATKIN, David. Neoclassical and $19^{\text {th }}$ century architecture. Milan: Electa, 1980.

SEGAWA, Hugo. Ao amor do público - Jardins no Brasil. São Paulo: Studio Nobel/Fapesp, 1996.

ZEVI, Bruno. Saber ver a arquitetura. Trad. Maria Isabel Gaspar e Gaëtan M. de Oliveira. São Paulo: Martins Fontes, 1996. 